\title{
The Long-Term Effects of Oppression: Prussia, Political Catholicism, and the Alternative für Deutschland
}

\author{
LUKAS HAFFERT University of Zurich, Switzerland
}

\begin{abstract}
C ontemporary political behavior is often affected by historical legacies, but the specific mechanisms through which these legacies are transmitted are difficult to pin down. This paper argues that historical political conflicts can affect political behavior over several generations when they trigger an enduring organizational mobilization. It studies how the oppression of German Catholics in the nineteenth century led to a regionally differentiated mobilization of political Catholicism that still affects political support for the radical right Alternative für Deutschland (AfD) today. Using newly collected data on historical oppression events, it shows that Catholic regions where oppression was intense saw greater mobilization of Catholic lay organizations than Catholic regions where oppression was milder and show lower support for the AfD today. The paper thus contributes to the literature on the historical determinants of political behavior as well as to the question of which regional context effects strengthen or weaken the radical right.
\end{abstract}

\section{INTRODUCTION}

W hy are people in some regions more willing to support the radical right while people in other regions are more reluctant to do so? A growing literature argues that such differences are partly driven by long historical continuities underlying political behavior (Cantoni, Hagemeister, and Westcott 2019; Hoerner, Jaax, and Rodon 2019; Homola, Pereira, and Tavits 2020; Ochsner and Roesel 2017). Where other studies emphasize contemporary economic or cultural grievances (Colantone and Stanig 2018; Gidron and Hall 2017; Inglehart and Norris 2016), these contributions seek the explanations for variation in radical right support in the past.

An important challenge for such arguments about historical persistence is pinning down the mechanism by which historical experiences are transmitted to later generations (Neundorf and Pop-Eleches 2020; Peisakhin and Charnysh 2021). How does a historical event affect people who are separated from this event by more than a century? Transmitting attitudes over such a long period usually requires some form of institutional stabilization. In this study, I emphasize the role of organizational mobilization as an important source of such stabilization. I argue that political conflicts can trigger the creation of persistent social and organizational structures that continue to shape people's behavior long after the original conflicts have been assuaged.

To examine this argument empirically, I study the relationship between the historical mobilization of Catholic lay organizations and the strength of the Alternative für Deutschland (AfD) in the German federal election of 2017. Catholicism has historically been

Lukas Haffert (D), Senior Researcher, Department of Political Science, University of Zurich, Switzerland, haffert@ipz.uzh.ch.

Received: January 04, 2021; revised: June 18, 2021; accepted: August 11, 2021. First published online: September 16, 2021. a factor that has heavily influenced the structure of the German party system and has inhibited people from voting for authoritarian parties (Falter 1991; Spenkuch and Tillmann 2018). This uniform effect of Catholicism, however, masks important regional variation in the historical development of political Catholicism. In some parts of Germany, particularly in Prussia, Catholics were oppressed by the state and developed a coherent and closed "milieu" $-\mathrm{a}$ dense network of Catholic clubs, associations, newspapers, and educational activities (Lepsius 1966) - in response to this oppression. In most other German states, by contrast, there was no comparable oppression and a similar milieu did not develop.

Against this background, I argue that the mobilization of the Catholic milieu provides the mechanism that links the regional history of oppression to contemporary AfD vote shares. Where Catholics were oppressed, they developed a tight-knit Catholic milieu whose remainders still form a social context that affects political behavior and reduces Catholics' propensity to vote for an authoritarian party. Where they were not oppressed, a comparable milieu did not develop and Catholics remained much more open to vote for such a party.

A look at the regional distribution of Catholics and of AfD results in West Germany in the federal election of 2017 provides some provisional support for this argument (Figure 1). The AfD has its strongest results in highly Catholic regions (in southeastern Bavaria). However, it also has its weakest results in regions where Catholicism is strong (along the Dutch border). One main difference between these regions is that the latter historically belonged to Prussia, whereas the former did not.

In the rest of the paper, I present more systematic evidence for this association. I measure historical oppression using two different strategies. First, I distinguish between places that historically belonged to Prussia and those that did not, as Catholics mainly 


\section{FIGURE 1. Prussian Borders in 1866, Share of Catholics in 2011, and AfD Vote Shares in 2017}

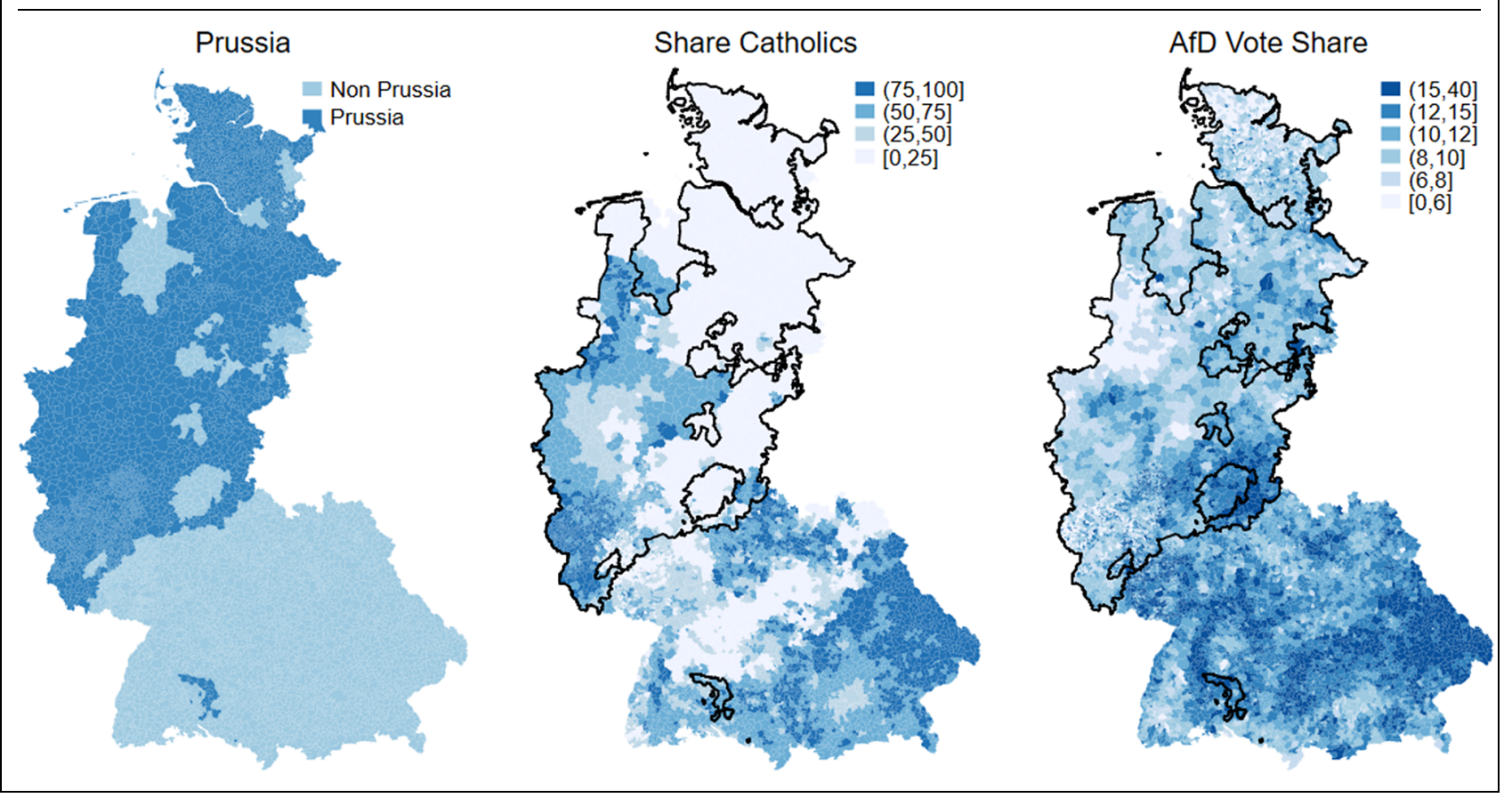

experienced oppression in Prussia. Second, I have collected data on about 500 specific events of Catholic oppression during the Kulturkampf in the years 1875 and 1876 . These events were chronicled by the Frankfurter Zeitung for the entire German empire and show huge regional variation in the intensity of oppression.

Using these alternative measures, I employ three different strategies to analyze the links between historical oppression and contemporary voting. First, using municipal-level election results across West Germany ${ }^{1}$, I demonstrate that the AfD performs significantly worse in Catholic regions where Catholics were oppressed than in Catholic regions without oppression. Second, I analyze this relationship within the state of Rhineland-Palatinate, exploiting the discontinuity at the former Prussian-Bavarian border within this state. Third, I also find evidence of a stronger rejection of the AfD among Catholics in historically oppressed regions in individual-level survey data.

Finally, I provide evidence of the mechanism underlying this relationship. Using data on the intensity of Catholic civil society mobilization in the early twentieth century, and on the Catholic lay milieu today, I show that the intensity of oppression predicts the strength of Catholic mobilization at the regional level and that mobilization levels in turn predict electoral behavior: Catholics are more heavily opposed to the AfD in regions where Catholics were highly mobilized in the past and in the present.

\footnotetext{
${ }^{1}$ I restrict my analysis to former West Germany, as my argument about the transmission of historical experiences relies on the continuity in the organizational and institutional context. In former East Germany, the combined effect of 56 years of fascist and socialist rule was to systematically dismantle this context.
}

This study thus contributes to the question how historical legacies are being transmitted. Moreover, it also addresses the literature on the role of regional context effects for the electoral success of the radical right (Fitzgerald 2018; Harteveld et al. 2021). In line with this literature, the study finds that the decision (not) to vote for the radical right is strongly influenced by regional context factors. However, it emphasizes that the role of this context is always historically specific. Living in a region that is majority Catholic can have very different effects on political behavior, depending on the region's historical trajectory.

In the following pages, I first explain how the historical oppression of Catholics led to specific forms of political mobilization and why this mobilization may still affect voting patterns today. In a second step, I explain the data and the empirical strategy. I then show that the association between historical oppression and Catholic AfD support holds at different levels of analysis before I analyze the mechanism behind this association. The final section discusses the implications of my findings and argues that understanding the variation in radical right voting requires analyzing not only the factors that attract certain people to the radical right but also those that inhibit others from voting for these parties.

\section{ARGUMENT}

\section{Theory: Mechanisms of Historical Persistence and the Role of Regional Contexts}

The rapidly growing literature on attitudinal legacies argues that a regionally specific history of political 
conflict can still affect political behavior decades or even centuries after the original event (Acharya, Blackwell, and Sen 2016; Peisakhin and Charnysh 2021; Putnam 1993). While this literature studies a wide range of empirical phenomena, a number of recent contributions specifically addresses historical patterns underlying the success of right-wing authoritarian parties (Ochsner and Roesel 2017; Voigtländer and Voth 2012), including the AfD (Cantoni, Hagemeister, and Westcott 2019; Hoerner, Jaax, and Rodon 2019; Homola, Pereira, and Tavits 2020).

There is thus wide agreement that regional historical legacies can affect political outcomes today. Where this literature has made less progress so far is in identifying the specific mechanisms by which historical experiences are transmitted to future generations - "the mechanisms underlying the persistence of political traits remain understudied" (Peisakhin and Charnysh 2021, 3). Neundorf and Pop-Eleches (2020), who share this assessment, seek to systematize potential mechanisms by identifying three "socialization agents" that play an important role in forming political attitudes and can be a source of attitudinal persistence. These "socialization agents" operate on the micro level (the family), the macro level (the state), or the meso level (societal organizations).

This paper emphasizes the role that meso-level organizations such as unions or churches can play for long-term persistence. While families clearly have an important role in explaining vertical transmission of attitudes from one generation to the next, they can hardly explain horizontal transmission to people whose ancestors did not yet share these attitudes. Similarly, states clearly have an important role in attitudinal transmission, in particular through the school system. However, macro-level mechanisms should typically generate a uniform pattern of transmission and thus have difficulties in explaining regional differences in historical persistence.

To explain a regionally specific form of persistence that is transmitted both vertically and horizontally, this paper thus focuses on the role of meso-level organizations as an important element of regional social contexts. These organizations can be understood as "integrative institutions" that play an important political role "as sites of mobilization and education" (Gingrich and Lynch 2019). Compared to micro- or macro-level socialization agents, these integrative institutions better ensure a vertical transmission since they are typically more enduring than individual families and outlast specific political regimes. The prime example of this persistence is Churches, but it also characterizes unions or even political parties. Moreover, integrative institutions can potentially transmit attitudinal legacies horizontally to individuals whose own ancestors did not live in a region. The children of newcomers, for example, may pick up a regionally specific set of attitudes through their integration in civil society organizations. Finally, integrative institutions may also aid the microlevel mechanisms of transmission. As Peisakhin and Charnysh $(2021,3)$ argue, "the transmission of values is more effective when families live in like-minded communities."

Organized religion, both through religious practices as well as through its role in the social life of a community as a provider of social services, education, and associational networks, is one of the most important integrative institutions. Several studies have shown that organized religion in general, and Catholicism in particular, can be a source of persistent socialization effects (Pop-Eleches and Tucker 2017). Jason Wittenberg (2006), for example, has analyzed how the Hungarian Catholic Church reinforced and protected traditional partisan affiliations, which then reemerged once Communism had been dismantled. Here, I go beyond these studies, which focus on Communism in Eastern Europe, by analyzing persistence over a much longer timespan of about 150 years. Moreover, my argument does not focus on the Church itself but on the lay-based civil society organizations at the heart of the Catholic milieu.

\section{The Empirical Case: Support for the Alternative für Deutschland}

The empirical case I use to study the persistent effects of meso-level organizations is the regionally differentiated success of the radical right Alternative für Deutschland in former West Germany. West Germany is a good case for studying these effects, as neither macro- nor micro-level factors are likely to explain long-term legacies. On the macro level, West Germany experienced four different political regimes over the last 150 years. On the micro-level, there was a lot of internal migration, in particular after 1945 (Cantoni, Hagemeister, and Westcott 2019), which makes it unlikely that legacies can be explained by transmission in the family alone.

The rise of the AfD in a country that long seemed immune against the radical right has, naturally, attracted a lot of attention. Most analyses follow the broader literature on support for radical right parties by focusing on one of two main explanatory approaches: an economic approach, which argues that "modernization losers" are the basis for these parties' electoral support, and a cultural approach, which attributes their success to a "cultural backlash" (Colantone and Stanig 2018; Gidron and Hall 2017; Inglehart and Norris 2016). As a growing number of studies have argued, however, such general approaches need to be complemented with regionally differentiated explanations that are sensitive to the role of social context (Fitzgerald 2018; Harteveld et al. 2021).

The existing literature on the AfD also points to the importance of historically determined regional context effects. Richter and Bösch $(2017,12)$ find that the AfD was particularly strong where the right-wing extremist NPD had performed best in 2013 and conclude that a "specific political-cultural climate ... promotes the success of the AfD in these districts." Similarly, Bergmann, Diermeier, and Niehues (2018) identify four socioeconomically very different regional AfD strongholds and conclude that the AfD's success results "more strongly from-probably cultural or historical-differences 
between the respective regions than from economic indicators" $(2018,261){ }^{2}$

These studies demonstrate that an explanation of the AfD vote should account for regional differences with deep historical roots. At the same time, they also point to an important research gap: while they measure historical persistence, they often fail to explain it, instead attributing it to rather vacuous "cultural" factors. By looking more closely at the oppression and political mobilization of Catholics as a specific historical mechanism, this study seeks to help fill this gap.

\section{Catholicism and Radical Right Voting}

That Catholicism may be a factor that inhibits people from voting for the extreme right is a prominent hypothesis in the German context. It typically builds on the observation that Catholics were particularly reluctant to support the NSDAP (Falter 1991). Because AfD results correlate with historical NSDAP results (Cantoni, Hagemeister, and Westcott 2019), this would suggest that Catholicism could play an important role in explaining the AfD's regionally differentiated success.

Theoretically, however, it is not clear a priori whether Catholics would be more or less likely to vote for authoritarian or radical right parties. On the one hand, Catholicism can be seen as having a natural affinity with illiberal and authoritarian politics, as they share an emphasis on hierarchy and tradition (Bruce 2003; Minkenberg 2018). On the other hand, Catholicism can also be seen as providing a bulwark against such politics by creating a strong attachment to Christian Democratic Parties (Minkenberg 2018) and by fostering values of solidarity and compassion (Siegers and Jedinger 2021). Indeed, comparative studies of European countries have found that religiosity can work as a "vaccine" against radical right voting (Arzheimer and Carter 2009). At the same time, it is possible that denominational Catholics become more susceptible to anti-immigrant/anti-Muslim agitation as their "religious integration" declines (Immerzeel, Jaspers, and Lubbers 2013; Meyer 2013).

As this literature emphasizes, it is necessary to distinguish between three different dimensions of Catholicism: formal denomination, actual involvement, and individual belief structures (Arzheimer and Carter 2009; Siegers and Jedinger 2021). These dimensions may have quite different effects on political behavior. Whereas religious involvement is said to generate a form of "social integration" that makes the support of a radical right party less likely, orthodox beliefs may have the opposite effect (Immerzeel, Jaspers, and Lubbers 2013). Simple denomination, finally, may have lost most of its historical effect on voting behavior.

This multidimensional perspective may help to explain why existing studies of Catholic support for the AfD have generated inconsistent findings. While analyses based on individual-level survey data have found that Catholics are less likely to support the

\footnotetext{
${ }^{2}$ All translations from German are my own.
}

AfD (Arzheimer and Berning 2019; Siegers and Jedinger 2021), studies based on regional election results have not found any correlation between Catholicism and AfD vote shares (Jäckle, Wagschal, and Kattler 2018; Richter and Bösch 2017).

My argument focuses on the dimension of religious involvement. However, involvement may affect political behavior through different mechanisms: an elitebased mechanism and a civil-society-based mechanism. The elite-based mechanism runs through the clergy: bishops and priests take a stand against authoritarian parties and thus inhibit Catholics from supporting them. This mechanism was at work in the 1930s. As Spenkuch and Tillmann (2018) show, Catholics did not support the NSDAP when being instructed to do so by the local priest. In parishes with "brown priests," by contrast, they became more willing to vote NSDAP. There is evidence that the Church still affects the voting behavior of individual Catholics (Immerzeel, Jaspers, and Lubbers 2013; Siegers and Jedinger 2021). However, it is unlikely to have major effects on aggregate electoral results anymore, given the low rates of church attendance. In 2019, only 9\% of Catholics attended church on regular Sundays (Katholische Kirche in Deutschland 2020).

Therefore, I focus on a different, potentially equifinal form of involvement that is more likely to affect the behavior of a substantial number of Catholics: integration in the Catholic civil society. I argue that the Catholic civil society creates a form social integration that reduces Catholic support for the AfD. The organizations at the heart of the Catholic civil society have about six million members (Katholische Kirche in Deutschland 2020). However, the mobilization of the Catholic civil society varies substantially across Germany for historical reasons. Specifically, I argue that there was strong regional variation in the intensity of Catholic oppression by the state, that this variation triggered differences in the intensity of Catholic countermobilization, and that these differences still affect voting behavior today. I briefly explain each of these arguments in turn.

\section{Historical Background: State-Church Conflict in Nineteenth-Century Germany}

After the Reformation, there remained two majorityCatholic regions in Germany: most parts of Southern Germany, including Bavaria, and large parts of NorthWestern Germany, including the Rhineland and Westphalia. Until the French Revolution, confessional borders and territorial borders were largely identical; therefore, almost all Catholics lived in Catholic states and there were no systematic differences in the relationship between Catholics and their states (Scholz 2016, 104). Therefore, the mobilization of Catholics did not differ systematically between regions before the nineteenth century.

This changed after mediatization and secularization in 1803 and, more importantly, after the Congress of Vienna, when the Rhineland and Westphalia became part of Prussia. After 1815, most Southern German 
Catholics still lived in Catholic states, whereas most Catholics in Northern Germany lived in Protestant Prussia. This had major consequences for the intensity of state-church conflict and the political mobilization of Catholics in the different regions. In particular, the conflict between state and Catholic Church was much more severe within Prussia than outside of it.

This conflict saw several outbursts over the entire nineteenth century. It reached an initial peak during the so-called Cologne troubles (Kölner Wirren) in the late 1830s. The Prussian government decreed that the children of marriages between (Protestant) civil servants and women from the local (Catholic) elite had to be educated in the confession of the father. When the Archbishop of Cologne refused to bless these marriages under this condition, the Prussian government imprisoned him for 18 months. This triggered a series of riots in Rhineland and Westphalia and more generally a political mobilization of Catholics as Catholicssomething that had not been seen before (Lönne 1986). Naturally, this type of conflict could not occur in majority-Catholic states.

The single most important conflict between Church and state, however, was the so-called Kulturkampf, which raged on between 1871 and 1887 but had its most dramatic phase between 1871 and 1875 . While this struggle affected the entire German empire, it was much more intense within Prussia than outside of Prussia (Ross 1998, 6; Strötz 2005, 211ff., 245). The "May laws," through which the state sought to gain direct influence over the selection of priests and bishops, were restricted to Prussia and some of Prussia's smaller neighboring states. The Prussian state also closed the Catholic seminaries (Strötz 2005, 308), temporarily imprisoned five bishops (Ross 1998, 58), and forced several thousand priests and members of religious orders into-often Bavarian-exile.

\section{The Formation of the Catholic Milieu}

These differences in the intensity of political conflict led to major differences in political mobilization. In response to their oppression, Prussian Catholics developed a dense network of Catholic clubs, associations, newspapers, educational activities, and a strong attachment to the Catholic party (Arbeitskreis für kirchliche Zeitgeschichte 2000). This dense network is known as the Catholic "milieu" (Lepsius 1966). But while literature in political sociology has often implicitly assumed a single homogenous Catholic milieu in the Catholic regions of the German empire, more recent historical research has clarified that the quintessential Catholic milieu only existed in Prussia, and even there it was not fully developed in all regions. According to a systematic review of historical studies of political Catholicism (Arbeitskreis für kirchliche Zeitgeschichte 2000), a full-fledged Catholic milieu developed mainly in Westphalia, the northern Rhine Province, and the southwestern part of today's Lower Saxony. In Southern Germany, by contrast, there dominated a more traditional, Church-focused form of Catholic mobilization. Finally, there was no strong formation of Catholic activities in regions where less than $15-20 \%$ of the population was Catholic.

These differences in the formation of the Catholic milieu were also reflected in the two politically most important forms of Catholic organization: Catholic associations and the Catholic party. At the association level, this is demonstrated by the katholischer Verein Deutschlands, which organized the Katholikentag festivals and was the "most important vehicle for mobilizing popular dissent against Bismarck's ecclesiastical policies" (Ross 1998, 129). While the organization targeted nationwide mobilization,

membership varied a good deal from region to region [...] most Bavarian Catholics were too particularistic to unite in a common enterprise of this sort with their coreligionists north of the Main River. The association also met with little success in expanding its membership in southwestern Germany. (Ross 1998, 129)

Similarly, the biggest Catholic association, the Volksverein für das katholische Deutschland (People's Association for Catholic Germany), which sought to promote Catholic education and Christian social reforms and attracted up to 800,000 members before World War I, had the majority of its members in Westphalia and the Rhine Province (Heitzer 1979; Klein 1996).

At the party level, the Catholic Centre Party always displayed weak national organization, in particular in comparison to the Social Democrats (Nipperdey 1961). The Party's Reichstag faction was more a collection of representatives from different regional parties than a coherent national party. Indeed, its Bavarian branchthe Bavarian Patriots' Party-did not change its name to the Bavarian Centre Party until 1887. Its interwar successor, the Bavarian People's Party (BVP), dissolved the joint parliamentary faction with the Centre Party in 1920. In the presidential election of 1925, the BVP even supported the national-conservative candidate Hindenburg instead of the Rhenish Centre politician Marx.

Historical literature thus shows that an organized and politically strongly mobilized Catholic milieu mainly emerged in the Prussian part of Germany. Here, political Catholicism developed in the form of the mobilization of societal actors against the state. It was deeply interwoven with society through a network of associations and the Centre Party and it opposed an authoritarian state. Moreover, as Margaret Anderson (1986) argues, the experience of the Kulturkampf and the political reaction to it led to an emancipation of Catholic laity from the Church hierarchy. Outside of Prussia, by contrast, political Catholicism developed as a Church-affiliated clerical movement with much weaker lay associations and was represented by a political party much more closely associated with the Church.

\footnotetext{
${ }^{3}$ This is necessarily a streamlined version of a multifaceted history, which attempts to identify the patterns that are most important for
} 


\section{The Catholic Milieu as a Mechanism of Historical Transmission}

My argument is that the formation of the Catholic milieu provides the mechanism by which historical experiences of political oppression were transmitted to later generations. Individual Catholics died, but the organizations they had created lived on. Indeed, milieus-not just the Catholic milieu but also the social-democratic milieu-have had a crucial influence on the development of the German party system (Lepsius 1966). According to Lösche and Walter (2000, 472), within these milieus "the experiences of primary conflicts were saved, intergenerationally bequeathed and organizationally solidified." Thus, they still affected voting behavior long after the original conflicts during which they were formed had been assuaged. The Catholic milieu even experienced a brief revival after World War II, when Catholic organizations were some of the few societal organizations that had survived the war relatively intact (Großbölting 2013), but has largely disappeared since the 1960s (Lösche and Walter 2000; Ziemann 2000). Nevertheless, its remnants still affect political behavior, as is evidenced by the fact that the religious cleavage still carries weight in explaining German election results (Elff and Rossteutscher 2011).

Thus, the political mobilization of Catholics in the nineteenth century may still affect voting behavior today. In the regions where Catholics historically mobilized through a Catholic milieu and where Catholics are still socialized in the remainders of this milieu, they should be much more reluctant to support the AfD for several reasons. First, the milieu historically created a strong attachment to a Christian party. Indeed, between 1871 and 1933, the Centre Party commanded more than $50 \%$ - and up to $80 \%$ - of the Catholic vote. Since World War II, Catholics have overproportionally supported the supraconfessional Christian Democrats, who still have their best election results in the former strongholds of the Centre Party. Second, remainders of the milieu such as Catholic sports clubs and other Catholic associations provide a form of social capital that is often seen as fostering democratic values and as inhibiting people from voting for the radical right (Coffé, Heyndels, and Vermeir 2007; Giuliano and Wacziarg 2020; Putnam 1993, but see Rydgren 2009). Indeed, the Zentralkomitee der deutschen Katholiken, the umbrella organization of Catholic associations, has repeatedly attacked the AfD and called on all Germans not to vote for the party (Zentralkomitee der deutschen Katholiken 2018). Several Catholic associations have declared that a membership in these associations is incompatible with an AfD membership (see Appendix J). Finally, since the milieu emerged during conflict with an authoritarian government, milieu socialization

contemporary politics but cannot do full justice to the complexity of Catholic history. Even in the Rhineland and Westphalia, the milieu was not completely homogenous but characterized by internal conflicts, for example between different classes (e.g., Jones 2000). may also foster skepticism toward authoritarian politics in general. Moreover, as milieu organizations, such as youth organizations, may form an important social context even for former Catholics or non-Catholics, especially during their formative years, these individuals may also refrain from voting AfD. In other words, the milieu may have worked as a mechanism of not only vertical but also horizontal transmission.

Where milieu-based lay movements played a smaller role in the development of political Catholicism by contrast, its antiauthoritarian effect was much weaker because it depended entirely on the Church. To put it provocatively, not voting for authoritarians was in itself an expression of obeying an authority.

When the Church had a strong and immediate effect on Catholic voting behavior, the effect may still have been the same as the milieu effect. When the Church lost its capacity to inhibit Catholics from voting for authoritarians, this elite-based mechanism of opposition to authoritarians disappeared. In the regions where Catholic lay organizations are strong, it could be replaced by an equifinal civil-society mechanism. In regions where Catholic lay organizations are weak, by contrast, Catholics should be much more open to supporting the AfD.

\section{DATA AND EMPIRICAL STRATEGY}

To test this argument, my empirical analysis proceeds in two steps. ${ }^{4}$ I first analyze the results of the German federal election of 2017 and show that the strength of the AfD differs between Catholic regions that have experienced high and low levels of oppression. Afterward, I study the organizational strength of the Catholic milieu in the early twentieth and early twenty-first centuries and show that the empirical pattern of Catholic voting today can indeed be explained by differences in the historical mobilization of political Catholicism.

Because a milieu is a social entity, I conduct most of my analyses on the regional level, studying municipallevel election results. There are more than 8,000 municipalities in West Germany, allowing me to study election outcomes on a fine-grained geographical level. The dependent variable in these analyses is the share of AfD votes among all (valid) votes cast in the municipality.

I restrict my analysis to former West Germany for two reasons. First, there are simply very few Catholics in former East Germany; thus, Catholicism can hardly contribute to explaining voting behavior in the East. More importantly, any mechanism of historical persistence was severely disrupted in East Germany, as the combined effect of 56 years of fascist and socialist rule was to systematically dismantle existing milieus, their party structures, and their civil society foundations (Kösters et al. 2009).

\footnotetext{
${ }^{4}$ Datasets and replication materials can be accessed at https://doi. org/10.7910/DVN/MURIT2.
} 
In the first part of the analysis, I focus on the persistent effect of oppression. The main independent variable in this analysis is the interaction between the Catholic population share and different measures of historical oppression. Since I seek to estimate the longterm effect of political conflict in the nineteenth century, there is a danger of introducing posttreatment bias by including control variables. At the same time, there is also a danger of omitted-variable bias-for example, because different Catholic regions have been differently exposed to the "refugee crisis" of 2015. Accordingly, I always estimate two models, one with contemporary controls and one without them.

In analyses with control variables, I include several potential explanatory factors that may correlate with Catholicism. The sociostructural composition of the municipality is measured by the total size of the population and the population shares of foreigners, women, and of people older than 65. To account for local economic structures, I control for the unemployment rate, the share of regular employment, and the local share of marginally employed (see Appendix A for descriptive statistics and a detailed discussion of the controls' rationale). I also add a dummy for universities (data from Apfeld 2019). Finally, a dummy for municipalities within 30 kilometers of the Austrian or Czech border controls for the argument that the AfD performs best in those regions where the most refugees arrived in 2015 (Jäckle, Wagschal, and Kattler 2018), which also happen to be highly Catholic.

In all regression models, I weight observations by the number of voters in the municipality. To control for spatial correlation across municipalities, I estimate Conley standard errors with a cutoff of $50 \mathrm{~km}$ using the procedure developed by Colella et al. (2019). Results are robust to varying the cutoff (see Appendix B). I include state-fixed effects to ensure that the results are not driven by institutional or other differences between German states that emerged after 1945. Moreover, I also replicate the analysis solely for the state of Rhineland-Palatinate. This state was created after World War II by merging a formerly Prussian North with a non-Prussian South and thus enables me to test my hypothesis while holding all state-level institutions constant. In a further step, I restrict my analysis to the historical border region within Rhineland-Palatinate, increasing the comparability of the treated and untreated regions even more.

Finally, I also study individual attitudes toward the AfD to address concerns of an ecological fallacy. I use data from the German Longitudinal Election Study (GLES), which contains information on the electoral district in which people live and thus allows me to link their expressed attitudes to the level of historical oppression and historical Catholic mobilization in their region.

My empirical strategy crucially relies on the assumption that the political mobilization of Catholics inside and outside of regions that became Prussian in the nineteenth century did not differ before 1815 . This assumption is particularly plausible for the analysis of the historical border region because the border did not follow preexisting divides, as I explain below and in Appendix E. To justify this assumption for all of West Germany, I provide additional historical references in Appendix D. Finally, in the same Appendix, I follow Barro and McCleary (2016) and study the geographical distribution of beatification and canonization processes as an-admittedly very rough-indicator of Catholic mobilization. The share of candidates for beatifications/canonizations coming from Prussian regions compared with non-Prussian regions increased substantially after 1815 . This indicates that the new minority position indeed triggered a change in the mobilization of Catholics.

\section{Measuring Historical Oppression}

I use two measures of historical oppression. The broader and more general measure is whether a municipality historically belonged to Prussia, since Prussia was the German state in which the conflict with the Catholic Church was most severe. This measure does not rely on a specific point but captures an entire history of state-church conflict. However, it does not distinguish its intensity within Prussia, nor does it differentiate between non-Prussian states at all.

To create a more fine-grained measure of oppression, I collected data on the intensity of the Kulturkampf, the single most important confrontation between the German state and the Catholic Church in the nineteenth century. The historical literature agrees that the Kulturkampf was most intense within Prussia but does not provide quantifiable measures of its regional intensity. To approximate such a measure, I rely on a contemporary newspaper source: between January 1875 and March 1876, the Frankfurter Zeitung published a biweekly "Kulturkampf Kalender" in which it listed oppression events of the previous weeks.

In total, the newspaper catalogued more than 1,200 instances of state oppression in the German empire. Of these, 774 took place in West Germany. While about a third of these entries report measures taken against Social Democrats or against the secular press, 512 refer to cases of the oppression of Catholics. Of these, 322 refer to the specific municipality of the event, 159 refer only to the court district where a court decision was made, and 31 refer to a diocese only. I aggregate these data on the level of the 89 court districts that existed in West Germany in the 1870s and count the number of events per 100,000 inhabitants in each district. In Appendix A, I explain the construction of the measure in greater detail. In Appendix C, I show that an alternative way to aggregate the data by normalizing it to the number of Catholics on the level of administrative districts leads to very similar results.

Figure 2 (left panel) shows the regional distribution of my index. The pattern that emerges is reassuringly similar to the characterization of the Kulturkampf in the historical literature. While 27 districts, mostly in Southern and in protestant Northern Germany, did not see a single oppression event, the strongest oppression occurred in Prussian districts: for the district of Kleve, I count 13 events per 100,000 inhabitants, while the 
FIGURE 2. Intensity of Kulturkampf and Share of Catholics with Volksverein Membership in 1913
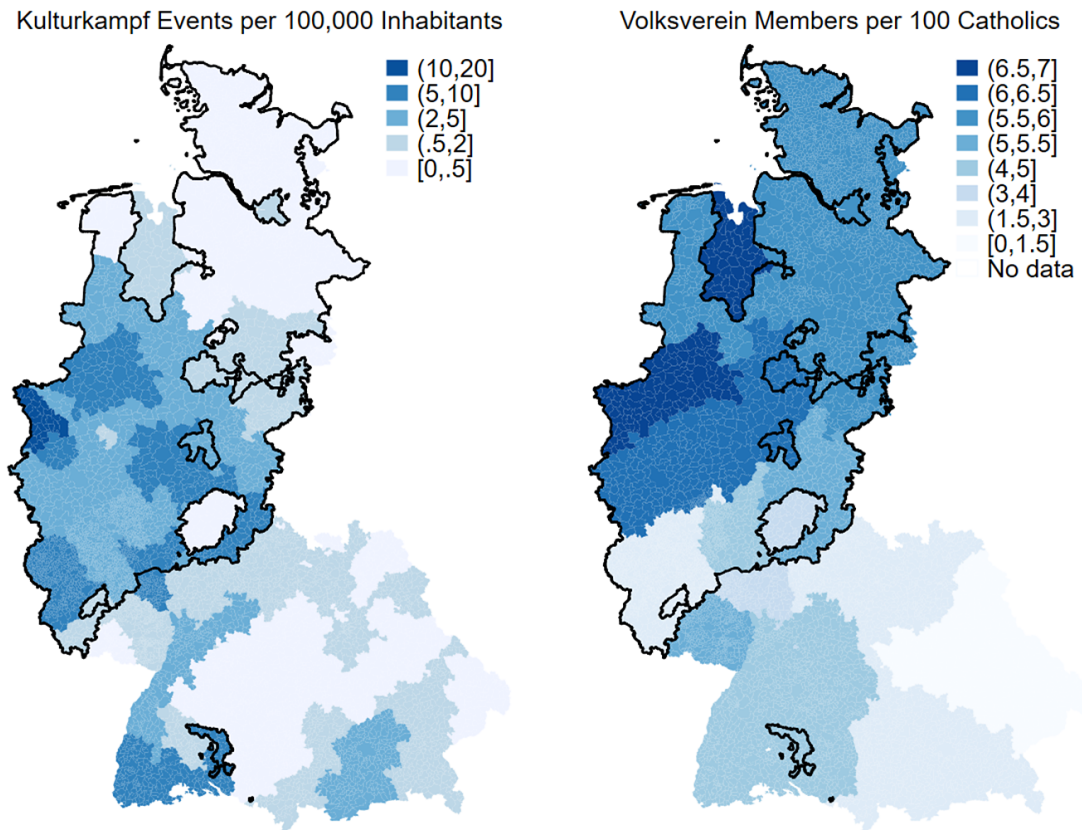

respective number was eight for Münster, Hanau, and Düsseldorf.

In the following analyses, I rely on both measures of oppression: the index of Kulturkampf intensity as well as whether a municipality belonged to Prussia. The former measure is more geographically fine-grained and based on actual oppression events. However, it only provides a snapshot from 1875 to 1876 . Whether or not a municipality belonged to Prussia better captures the entire history of Catholic oppression in the nineteenth century but does not provide regional differentiation. Reassuringly, both measures generate very similar results.

\section{Measuring Catholic Mobilization}

In the second step of my analysis, I study the mechanism that connects historical oppression to contemporary electoral outcomes and seek to show that this effect is driven by differences in Catholic mobilization. To measure Catholic mobilization, I use the strength of Catholic associations at the beginning of the twentieth century. I use data on the regional membership of the aforementioned Volksverein für das katholische Deutschland, the largest Catholic association, which was founded in 1890. I have data on the share of Volksverein members among all Catholics on the diocese level for 1913 and 1927 from the books by Heitzer (1979) and Klein (1996). At both points, the Volksverein consistently organized a higher share of the Catholic population within Prussia than outside of Prussia (Figure 2, right panel).

\footnotetext{
${ }^{5}$ For descriptive statistics, see Appendix A.
}

A contemporary measure of what remains of the Catholic milieu is the participation in the biannual Katholikentag festivals, the biggest gathering of German Catholics. ${ }^{6}$ During the German Empire, these festivals were manifestations of Catholic opposition to Prussian oppression. They therefore have their roots in the mobilization of the Catholic milieu, even if they have acquired a more event-like character today. The last Katholikentag in Münster had about 90,000 participants. Katholikentag participation is a good indicator of the persistent strength of the Catholic milieu because participants often do not attend individually but in groups organized by local chapters of Catholic associations. Their ability to mobilize participants for the Katholikentag thus proxies the more general strength of Catholic lay organizations.

The organizing committee provided me with data on the number of participants from each German diocese at the last 7 Katholikentag festivals. To calculate whether a diocese is over- or underrepresented at the Katholikentage, I divide the share of participants from a diocese by the share of German Catholics living there. I then regress this relative participation rate on the distance and the squared distance between a diocese's diocesan town and the Katholikentag location, as participation strongly varies with geographic distance.

\footnotetext{
${ }^{6}$ I have also collected data on membership in Catholic associations, but their regional patterns differ substantially between associations and it is unclear to what extent these differences already emerged in the nineteenth century.

${ }^{7}$ The festivals were spread across Germany. One took place in East Germany (Leipzig), three in formerly Prussian West Germany (Münster, Osnabrück, and Saarbrücken), and three in West German cities outside of Prussia (Regensburg, Mannheim, and Ulm). For descriptive statistics, see Appendix A.
} 
TABLE 1. AfD Vote Share on the Municipal Level 2017, West Germany

\begin{tabular}{|c|c|c|c|c|c|}
\hline & (1) & (2) & (3) & (4) & (5) \\
\hline DV: AfD vote share in 2017 & Catholic & Interaction & Full model & Intensity & Intensity controls \\
\hline Share Catholics & $\begin{array}{l}-0.010 \\
(0.013)\end{array}$ & $\begin{array}{l}0.029^{+} \\
(0.016)\end{array}$ & $\begin{array}{l}0.022^{+} \\
(0.012)\end{array}$ & $\begin{array}{l}0.029^{+} \\
(0.015)\end{array}$ & $\begin{array}{l}0.025^{\star} \\
(0.010)\end{array}$ \\
\hline Prussia & & $\begin{array}{l}1.468^{\star \star \star} \\
(0.497)\end{array}$ & $\begin{array}{c}1.299^{\star \star \star} \\
(0.360)\end{array}$ & & \\
\hline Prussia $\times$ Catholic & & $\begin{array}{c}-0.080^{\star \star \star} \\
(0.019)\end{array}$ & $\begin{array}{c}-0.053^{\star \star \star} \\
(0.014)\end{array}$ & & \\
\hline Kulturkampf intensity & & & & $\begin{array}{l}0.319^{+} \\
(0.162)\end{array}$ & $\begin{array}{l}0.361^{\star *} \\
(0.109)\end{array}$ \\
\hline Kulturkampf $\times$ Catholic & & & & $\begin{array}{c}-0.013^{\star * *} \\
(0.003)\end{array}$ & $\begin{array}{c}-0.011^{\star \star \star} \\
(0.002)\end{array}$ \\
\hline Unemployment & & & $\begin{array}{c}1.262^{* * *} \\
(0.147)\end{array}$ & & $\begin{array}{c}1.243^{\star \star \star *} \\
(0.130)\end{array}$ \\
\hline Marginal employment & & & $\begin{array}{c}-0.345^{\star \star *} \\
(0.096)\end{array}$ & & $\begin{array}{c}-0.314^{\star \star \star} \\
(0.089)\end{array}$ \\
\hline Regular employment & & & $\begin{array}{c}0.202^{* \star *} \\
(0.037)\end{array}$ & & $\begin{array}{c}0.192^{\star \star \star} \\
(0.034)\end{array}$ \\
\hline Population & & & $\begin{array}{c}-0.002^{* * \star} \\
(0.000)\end{array}$ & & $\begin{array}{c}-0.002^{* \star *} \\
(0.000)\end{array}$ \\
\hline University & & & $\begin{array}{l}-1.762^{\star \star \star} \\
(0.336)\end{array}$ & & $\begin{array}{c}-1.919^{\star \star \star} \\
(0.334)\end{array}$ \\
\hline Share foreigners & & & $\begin{array}{c}0.006 \\
(0.035)\end{array}$ & & $\begin{array}{l}-0.003 \\
(0.030)\end{array}$ \\
\hline Population > 65 & & & $\begin{array}{l}0.071^{\star} \\
(0.035)\end{array}$ & & $\begin{array}{l}0.058^{+} \\
(0.033)\end{array}$ \\
\hline Female population share & & & $\begin{array}{l}-0.457^{\star * \star} \\
(0.102)\end{array}$ & & $\begin{array}{c}-0.453^{\star * \star} \\
(0.088)\end{array}$ \\
\hline Close to border & & & $\begin{array}{l}1.582^{+} \\
(0.808)\end{array}$ & & $\begin{array}{l}1.530^{\star} \\
(0.691)\end{array}$ \\
\hline Constant & $\begin{array}{c}8.384^{\star * *} \\
(0.391)\end{array}$ & $\begin{array}{c}7.271^{\star * *} \\
(0.620)\end{array}$ & $\begin{array}{c}21.724^{\star \star \star} \\
(5.698)\end{array}$ & $\begin{array}{c}8.144^{* * *} \\
(0.413)\end{array}$ & $\begin{array}{c}22.951^{* * *} \\
(4.544)\end{array}$ \\
\hline $\mathrm{N}^{2}$ & 8,370 & 8,370 & 8,178 & 8,370 & 8,178 \\
\hline$R^{2}$ & 0.260 & 0.318 & 0.536 & 0.326 & 0.546 \\
\hline
\end{tabular}

I use the standardized residuals from this regression to calculate a diocese's mobilization. According to this measure, mobilization was strongest in the diocese of Osnabrück and weakest in the diocese of Passau.

\section{EMPIRICAL ANALYSIS}

\section{West Germany}

I first analyze the relationship between Catholicism, oppression, and AfD vote shares in all of West Germany. When looking at the share of Catholics in isolation, there is no correlation to AfD votes (Table 1, Model 1). However, when interacted with my simplest measure of oppression-whether a municipality historically belonged to Prussia-Catholicism has a strong effect, which works in opposite directions within and outside of Prussia (Model 2). This effect becomes slightly weaker when control variables are included but remains substantively important (Model 3).
Based on Model 2, Figure 3 shows how strongly the predicted AfD share diverges with a growing share of Catholics. While this predicted share is almost identical for municipalities with few Catholics, the predicted AfD result in Prussian municipalities becomes significantly lower than the result in non-Prussian municipalities when the share of Catholics approaches $40 \%$. As the median municipality in West Germany has a Catholic share of $35.1 \%$, this affects a substantial number of municipalities.

Finally, in Models 4 and 5, I use my measure of Kulturkampf intensity as a more fine-grained measure of historical oppression. I effectively replicate Models 2 and 3 but replace the Prussia dummy with the Kulturkampf index and cluster standard errors at the level at which oppression is measured (these errors are very similar to the Conley standard errors reported in the other specifications, see Appendix B).

As the analysis shows, there is indeed a significant interaction between the regional intensity of the $\mathrm{Kul}$ turkampf and the Catholic population share today. In regions where the historical oppression of Catholics 
FIGURE 3. Predicted AfD Vote Share in Municipalities within and outside of Former Prussia ${ }^{8}$

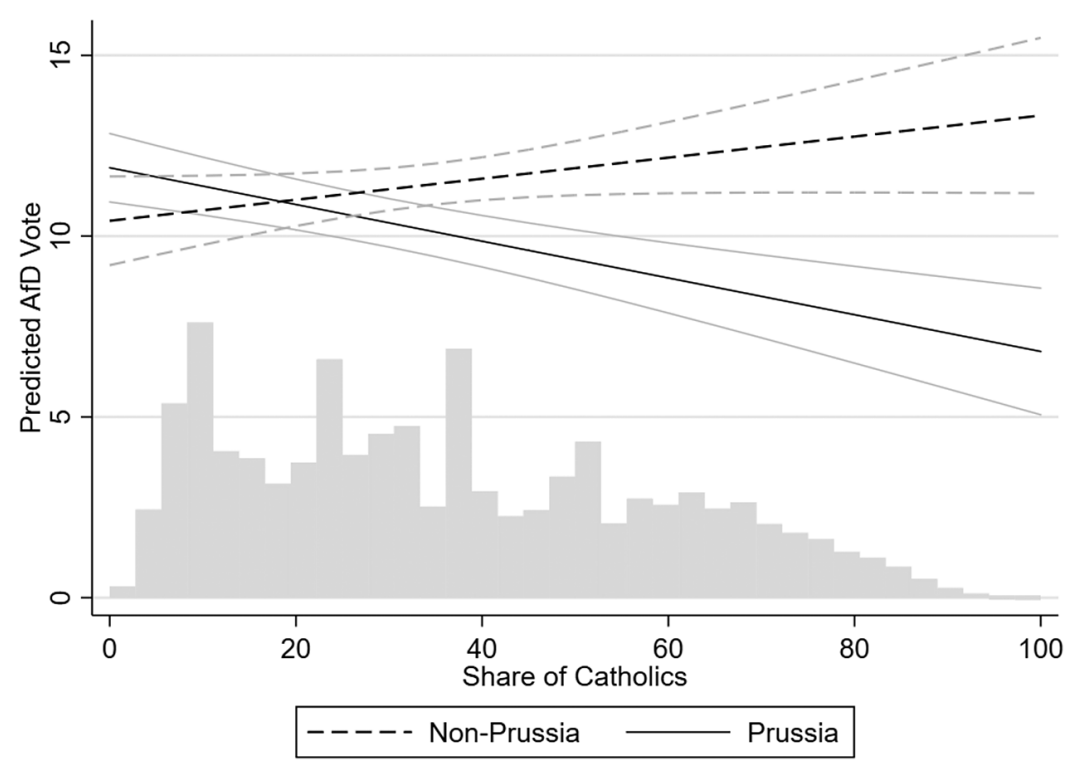

FIGURE 4. Intensity of Kulturkampf and Marginal Effect of Catholicism on AfD Vote Share ${ }^{9}$

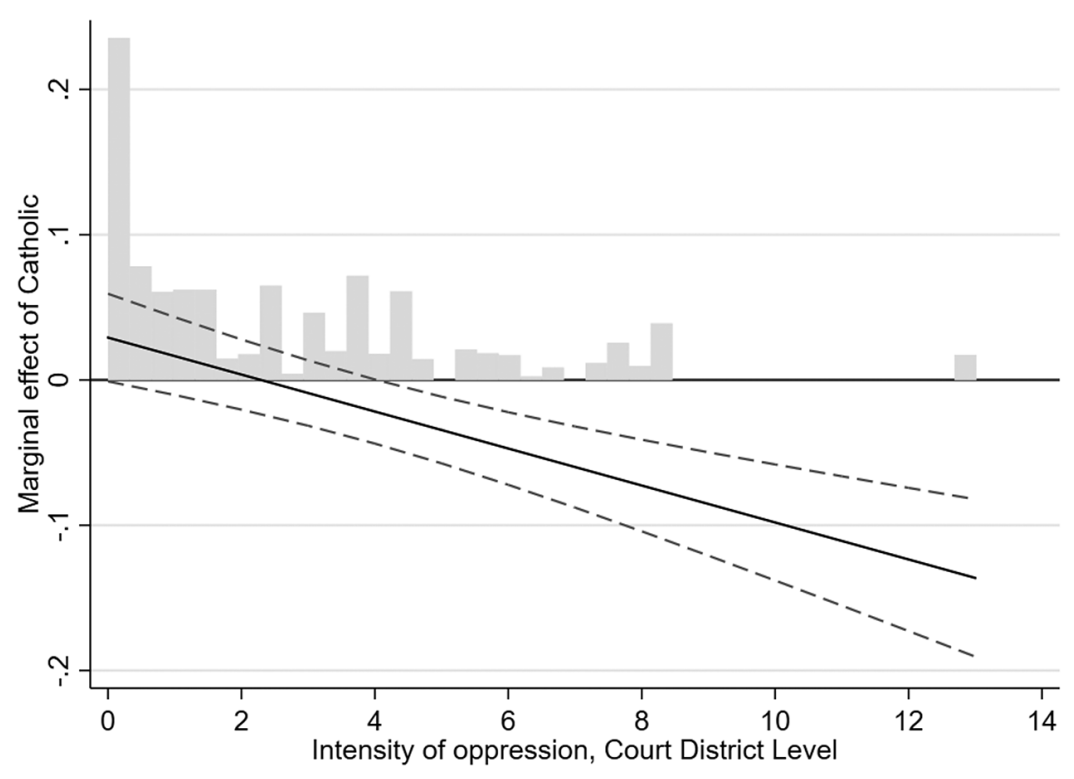

was strong, the Catholic population share is negatively related to AfD vote shares. In regions where oppression was weak, by contrast, Catholic population shares and AfD performance are not significantly related. Figure 4 demonstrates this relationship based on the results of Model 4.

In Appendix C, I provide additional robustness checks. I replicate the regression for the 2,586 municipalities in which Catholics represent at least two thirds

\footnotetext{
${ }^{8}$ The histogram shows the share of voters living in municipalities with a certain share of Catholics.
}

of the population in order to reduce the risk of an ecological fallacy. In this analysis of very Catholic regions, the estimated effect of Catholicism remains statistically significant and becomes substantively greater. Moreover, I study whether the effect of Prussian rule also holds for former East Germany. As expected, there is no such effect. In fact, there is a weak negative direct effect of Catholicism but no significant difference between Prussian and non-Prussian

\footnotetext{
${ }^{9}$ The histogram shows the share of voters living in municipalities that experienced a certain level of oppression.
} 


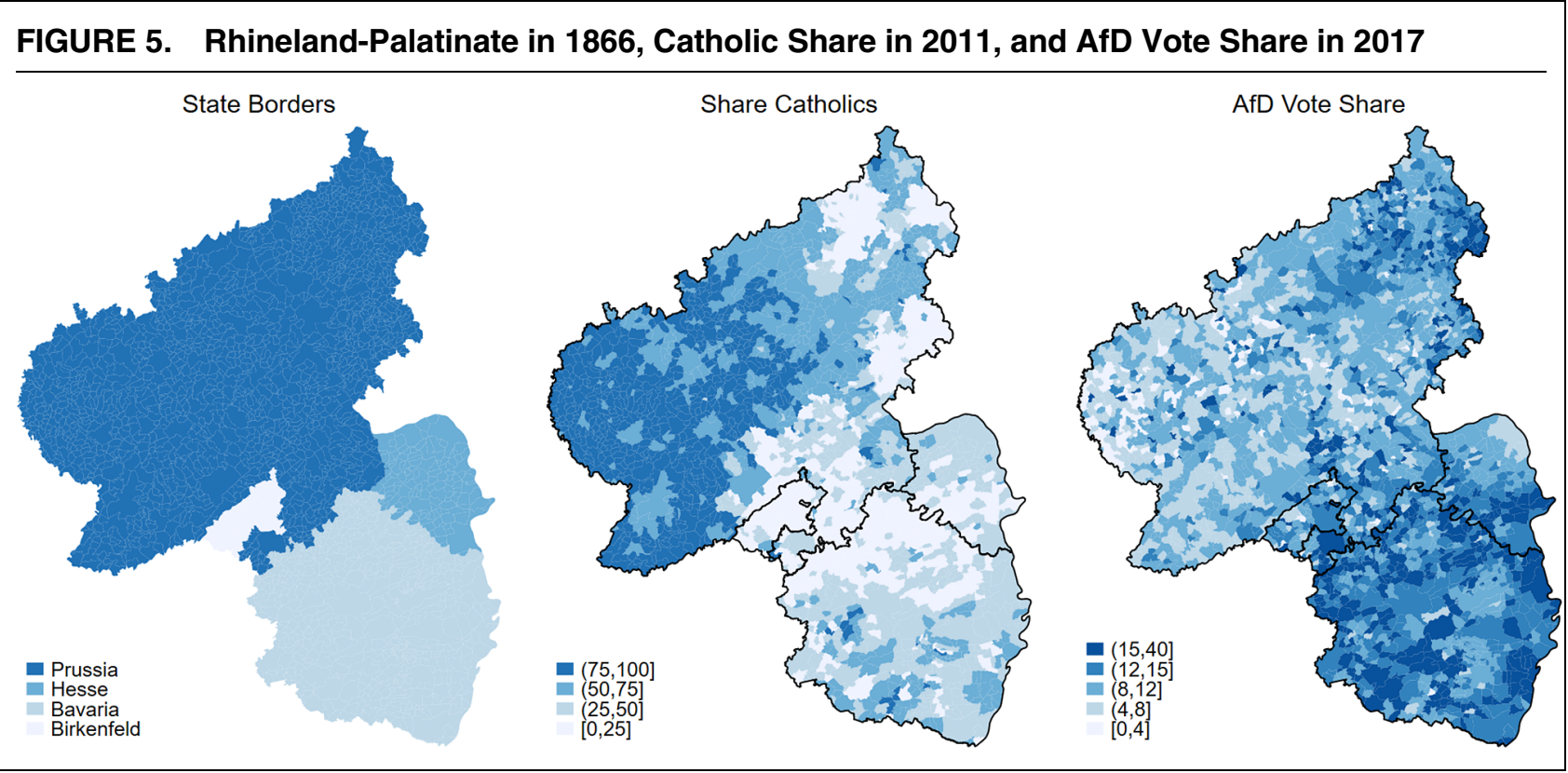

Catholics. In additional analyses, I remove the statefixed effects from the regression or add historical control variables. The results remain substantively the same.

In summary, these analyses show that Catholic regions where Catholics were oppressed during the nineteenth century have been much more resistant to the AfD than Catholic regions where little oppression occurred. Sociodemographic and labor-market related differences cannot explain these regional patterns.

\section{Rhineland-Palatinate}

The models presented so far included state-fixed effects to control for the possibility that idiosyncratic differences between German states that occurred after 1945 are the true reason behind the apparent Prussia effect. A second concern is that Catholic regions may have already differed before 1815 and that my analysis simply picks up these differences. To tackle these issues, I seek to analyze two regions where Catholics experienced few systematic differences before 1815 , were subjected to a very different treatment after 1815 , and became embedded in the same institutional context after 1945. The best candidate for such a region is the former Prussian-Bavarian border region in the state of Rhineland-Palatinate, which was created as a "Bindestrich-Bundesland" (hyphen-state) after World War II.

The area that came to be Rhineland-Palatinate consisted of dozens of independent territories before the French revolution and was occupied by France between 1794 and 1814 (see Appendix E). After the congress of Vienna, the northern part of the state became part of Prussia, the southern part was allocated to Bavaria, and the Eastern region around today's state capital of Mainz went to Hesse-Darmstadt (Figure 5 left panel). Moreover, three smaller German states received territorial compensation for losses or unfulfilled promises in other parts of Germany. The necessary territories were taken from the region between Prussia and Bavaria. The size of these compensations was defined by the number of inhabitants: Oldenburg received a territory with 20,000 inhabitants and so on. Thus, borders were drawn to create the necessary numbers and did not necessarily respect historical attachments. With the exception of the Oldenburgian territory of Birkenfeld, these territories later went to Prussia. The Duke of Saxe-Coburg-Saalfeld sold his territory to Prussia in 1834 , while the Homburgian territory of Meisenheim was annexed in 1866. These transactions generated the longest portion of the border between Prussia and Bavaria. This history suggests that the borders that emerged in the nineteenth century did not follow any systematic preexisting differences in the behavior or treatment of Catholics. ${ }^{10}$

However, Catholics were treated very differently in Prussia than in Bavaria after 1815. In Hesse-Darmstadt, the third major region and a majority Protestant state, Catholics also experienced heavy oppression. Wilhelm Emmanuel von Ketteler, the Bishop of the Hessian diocese Mainz from 1850 to 1877 , was one of the most prominent Catholic opponents of Bismarck and was imprisoned for two years starting in 1873 .

In summary, Rhineland-Palatinate is a good test case because Catholics in the northern and in the southern part of the state were arguably not treated systematically differently before 1815 , were treated very differently between 1815 and 1933, and were then again treated equally after 1945. Finally, there is enough variation in the share of Catholics in both the Prussian and non-Prussian part of the state to allow the estimation of an interaction effect.

\footnotetext{
${ }^{10}$ Diocesan borders were also redrawn to fit the new political borders.
} 
TABLE 2. AfD Vote Share on the Municipal Level 2017, Rhineland-Palatinate

\begin{tabular}{|c|c|c|c|c|c|}
\hline & (1) & $(2)$ & (3) & (4) & (5) \\
\hline DV: AfD vote share in 2017 & Catholic & Interact & Full model & Kulturkampf & Kulturkampf controls \\
\hline Share Catholics & $\begin{array}{c}-0.088^{\star \star *} \\
(0.013)\end{array}$ & $\begin{array}{l}-0.050 \\
(0.042)\end{array}$ & $\begin{array}{l}-0.027 \\
(0.027)\end{array}$ & $\begin{array}{c}-0.033^{\star \star \star} \\
(0.009)\end{array}$ & $\begin{array}{c}-0.018^{\star \star \star} \\
(0.005)\end{array}$ \\
\hline Prussia & & $\begin{array}{l}-0.658 \\
(1.125)\end{array}$ & $\begin{array}{l}-0.580 \\
(0.892)\end{array}$ & & \\
\hline Prussia $\times$ Catholic & & $\begin{array}{l}-0.023 \\
(0.043)\end{array}$ & $\begin{array}{l}-0.016 \\
(0.029)\end{array}$ & & \\
\hline Kulturkampf intensity & & & & $\begin{array}{c}-0.520^{\star \star \star} \\
(0.083)\end{array}$ & $\begin{array}{l}-0.339^{\star *} \\
(0.129)\end{array}$ \\
\hline Kulturkampf $\times$ Catholic & & & & $\begin{array}{c}-0.004^{+} \\
(0.002)\end{array}$ & $\begin{array}{l}-0.004^{\star} \\
(0.002)\end{array}$ \\
\hline Controls & NO & NO & YES & NO & YES \\
\hline $\begin{array}{l}N \\
R^{2}\end{array}$ & $\begin{array}{l}2301 \\
0.233\end{array}$ & $\begin{array}{l}2301 \\
0.269\end{array}$ & $\begin{array}{l}2190 \\
0.530\end{array}$ & $\begin{array}{l}2301 \\
0.412\end{array}$ & $\begin{array}{l}2190 \\
0.583\end{array}$ \\
\hline
\end{tabular}

Figure 5 already suggests that the results for West Germany also apply to Rhineland-Palatinate: the AfD received its highest vote shares in the Bavarian Palatinate and its lowest vote shares in the most Catholic areas of the former Prussian Rhine Province. To provide more systematic evidence for this relationship, I first replicate the analyses from above just for this state. Afterward, I restrict my analysis to the immediate region along the historical Prussian-Bavarian border in order to exploit the discontinuity in the treatment of Catholics that occurred at this border.

Table 2 reports the same regressions as already presented, just restricted to Rhineland-Palatinate. In contrast to the analysis for West Germany, there is a strong direct negative correlation between Catholicism and the AfD vote. This is not unexpected, as Prussian Catholics alone constitute $61 \%$ of all Catholics in Rhineland-Palatinate, whereas they make up only $47 \%$ of all Catholics in West Germany. Together with the oppression of Hessian Catholics, this makes it more likely to find an aggregate negative effect.

Nevertheless, this direct effect masks important variation in the behavior of Catholics in different parts of the state. However, simply adding an interaction with Prussia, as in the analysis for West Germany, just splits the effect of Catholicism into an insignificant direct effect and another insignificant interaction effect (Models 2 and 3). As Models 4 and 5, which include the continuous measure of Kulturkampf intensity indicate, however, this is largely caused by the disparate treatment of Catholics in Hesse and Bavaria. If the level of oppression is differentiated between these areas, the effect of oppression becomes significant. The more intense the oppression, the greater the negative relationship between Catholicism and the AfD. This suggests that the effect of Catholicism is not about Prussia as such but rather about the level of oppression.

These analyses include all municipalities within the state. In a second step, I restrict my analysis to the immediate border region to further improve the comparability of Prussian and non-Prussian municipalities. Following the discussion above, I focus on the Prussian-Bavarian border, which emerged through a rather random historical process and separates two regions where Catholics were treated very differently. I thus restrict the analysis to the 356 municipalities within 25 kilometers of the Prussian-Bavarian border (excluding municipalities in former Birkenfeld or Hesse) and add an interaction with the distance to the border to the "Prussia $\times$ Catholic" interaction. The average municipality in this sample has a Catholic population share of $31 \%$ with a standard deviation of $14 \%$. Because I am interested in an interaction effect, I cannot set the cutoff much lower, as I would otherwise lose too much variation in the share of Catholics on the Bavarian side of the border.

This is not a clean RDD, as the municipalities on both sides of the border are not statistically indistinguishable (those on the Prussian side are on average slightly more Catholic, see Appendix E), but it reduces the differences between municipalities as much as possible. Moreover, I am not interested in the direct effect of the historical state but in the interaction effect between state and Catholicism.

Appendix E reports the full model with and without controls. In Figure 6, I show the predicted values from the regression without controls for a municipality with a Catholic population share one standard deviation below the mean (17\%, left panel) and for a municipality with a Catholic population share one standard deviation above the mean ( $45 \%$, right panel). As the figure shows, there is no discontinuity at the border for municipalities with a low share of Catholics. In municipalities with a high share of Catholics, by contrast, the predicted AfD result is considerably lower on the Prussian side of the border. There is thus evidence of a persistent effect of oppression even in a region that is as homogenous as possible and has been part of the same institutional structure for more than 70 years. 


\section{FIGURE 6. Predicted AfD support at Low and High Levels of Catholicism}

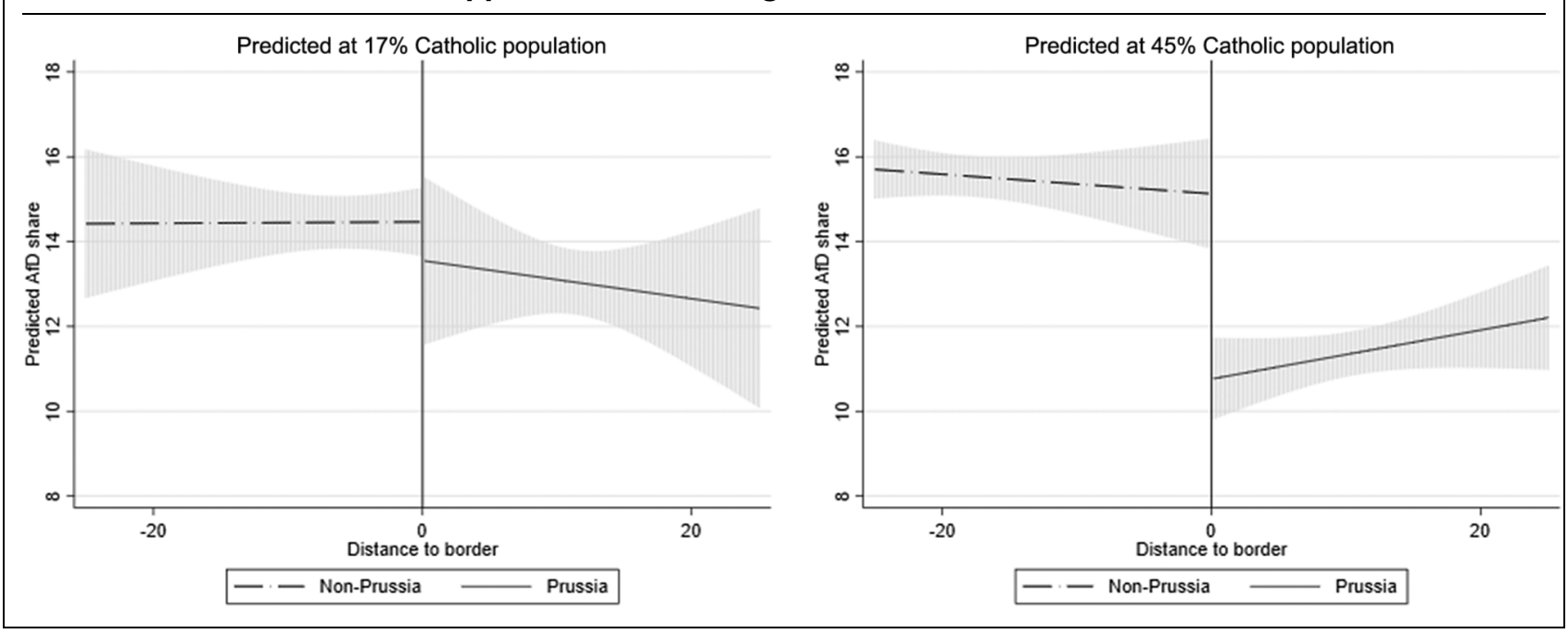

TABLE 3. Association between Kulturkampf Intensity and Catholic Mobilization

\begin{tabular}{|c|c|c|c|}
\hline & (1) & (2) & (3) \\
\hline DV: Catholic mobilization & Volksverein 1913 & Volksverein 1927 & Katholikentage \\
\hline Kulturkampf & $\begin{array}{c}0.552^{\star \star \star *} \\
(0.132)\end{array}$ & $\begin{array}{l}0.356^{\star} \\
(0.127)\end{array}$ & $\begin{array}{c}0.362^{\star \star \star} \\
(0.093)\end{array}$ \\
\hline $\begin{array}{l}N \\
R^{2}\end{array}$ & $\begin{array}{c}89 \\
0.298\end{array}$ & $\begin{array}{c}89 \\
0.208\end{array}$ & $\begin{array}{c}89 \\
0.252\end{array}$ \\
\hline
\end{tabular}

Note: Standard errors clustered on diocese level in parentheses; ${ }^{+} p<0.10,{ }^{\star} p<0.05,{ }^{\star \star} p<0.01,{ }^{\star \star \star} p<0.001$.

\section{Evidence on the Mechanism}

As the analyses have shown so far, there are substantial differences in the voting behavior between Catholic regions whose inhabitants have historically been subjected to high and low degrees of oppression. Can these differences indeed be explained by the disparate development of the Catholic milieu in the late nineteenth and early twentieth century? To test this, I proceed in two steps. I first show that the historical intensity of regional oppression predicts the strength of Catholic mobilization. I then provide evidence that AfD vote shares in 2017 are systematically related to the strength of the Catholic milieu throughout the twentieth century.

To test whether the historical degree of oppression predicts the strength of Catholic mobilization, I regress my three measures of Catholic mobilization on my measure of Kulturkampf intensity (Table 3). Since Kulturkampf intensity is measured at the court district level, I also estimate the regression at this level and cluster standard errors at the diocese level. To make the results more comparable, I standardize dependent and independent variables. For all three measures, there is a significant association between the two measures. Indeed, Kulturkampf intensity explains about a quarter of the variation in the regional strength of Catholic mobilization.

To test whether the strength of the Catholic milieu in the early twentieth century indeed affects the voting behavior of Catholic regions today, I repeat the already familiar regression but interact the Catholic population share with the continuous measures of Volksverein strength. As the regression results show, there is again a significant interaction effect between this measure of the strength of the milieu and today's share of Catholics in a municipality. This is the case for both the prewar measure (Table 4, Model 1) and the interwar measure (Table 4, Model 2). As Figure 7 shows, high regional Volksverein membership is associated with a negative effect of Catholicism on AfD share in 2017, whereas low Volksverein membership is associated with no or even a positive effect of Catholicism.

Obviously, the Volksverein was just one specific type of Catholic association and cannot be taken as a direct measure of the strength of Catholic associations, let alone the Catholic milieu. However, as the discussion above has shown other indicators of the strength and coherence of the Catholic milieu paint a similar picture. The immediate mobilization of the Catholic milieu was, thus, stronger in regions where oppression was more intense, and these differences are associated 
TABLE 4. Analysis of Mechanism ${ }^{11}$

\begin{tabular}{|c|c|c|c|c|}
\hline & (1) & (2) & (3) & (4) \\
\hline DV: AfD vote share & Volksverein 1913 & Volksverein 1927 & Katholikentag & Attendance \\
\hline Share Catholics & $\begin{array}{l}0.106^{\star \star} \\
(0.032)\end{array}$ & $\begin{array}{l}0.079^{\star *} \\
(0.025)\end{array}$ & $\begin{array}{l}-0.013 \\
(0.011)\end{array}$ & $\begin{array}{c}-0.212^{\star \star \star} \\
(0.030)\end{array}$ \\
\hline Volksverein 1913 & $\begin{array}{l}1.502^{\star \star} \\
(0.431)\end{array}$ & & & \\
\hline Volksverein '13 × Catholic & $\begin{array}{c}-0.026^{\star \star *} \\
(0.006)\end{array}$ & & & \\
\hline Volksverein 1927 & & $\begin{array}{l}1.652^{\star * \star} \\
(0.274)\end{array}$ & & \\
\hline Volksverein '27 × Catholic & & $\begin{array}{l}-0.038^{\star *} \\
(0.010)\end{array}$ & & \\
\hline Katholikentag participation & & & $\begin{array}{c}1.092 \\
(0.847)\end{array}$ & \\
\hline Katholikentag $\times$ Catholic & & & $\begin{array}{l}-0.070^{\star \star \star} \\
(0.018)\end{array}$ & \\
\hline Church attendance & & & & $\begin{array}{c}-0.558^{\star} \\
(0.198)\end{array}$ \\
\hline Attendance $\times$ Catholic & & & & $\begin{array}{c}0.020^{\star \star \star} \\
(0.003)\end{array}$ \\
\hline Constant & $\begin{array}{c}0.023 \\
(2.448)\end{array}$ & $\begin{array}{c}3.687^{\star * *} \\
(0.803)\end{array}$ & $\begin{array}{c}7.571^{\star \star \star} \\
(0.950)\end{array}$ & $\begin{array}{c}13.237^{* \star \star} \\
(1.679)\end{array}$ \\
\hline$N$ & 8,368 & 8,368 & 8,368 & 8,368 \\
\hline$R^{2}$ & 0.346 & 0.339 & 0.351 & 0.345 \\
\hline
\end{tabular}

FIGURE 7. Regional Strength of the Volksverein and Marginal Effect of Catholicism on AfD Vote
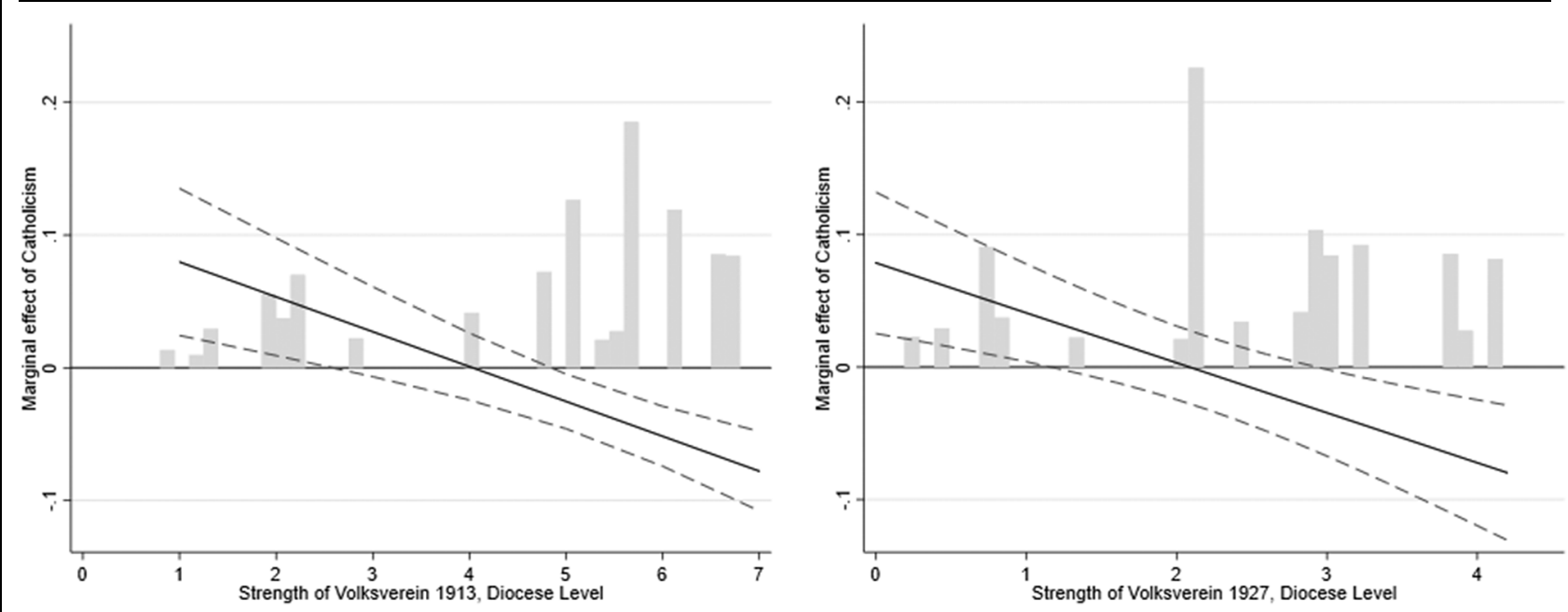

with differences in voting behavior today. But has this association persisted?

To test this, I use my data on Katholikentag participation in the twenty-first century. Again, we observe the now familiar interaction effect between the measure of the Catholic milieu and Catholic population

\footnotetext{
${ }^{11}$ As Appendix E shows, results are robust to the inclusion of contemporary control variables.
}

shares (Table 4, Model 3). In dioceses that are overproportionally represented at the Katholikentag festivals, the Catholic population share is negatively associated with the AfD result in the election of 2017. This is not the case in dioceses that are underrepresented at these festivals (Figure 8).

As discussed above, an alternative mechanism prominently discussed in the literature, in particular on the interwar period, is the role of the clergy. Arguably, this elite-based mechanism should make practicing 
FIGURE 8. Participation at Katholikentag Festivals and Marginal Effect of Catholicism on AfD Share

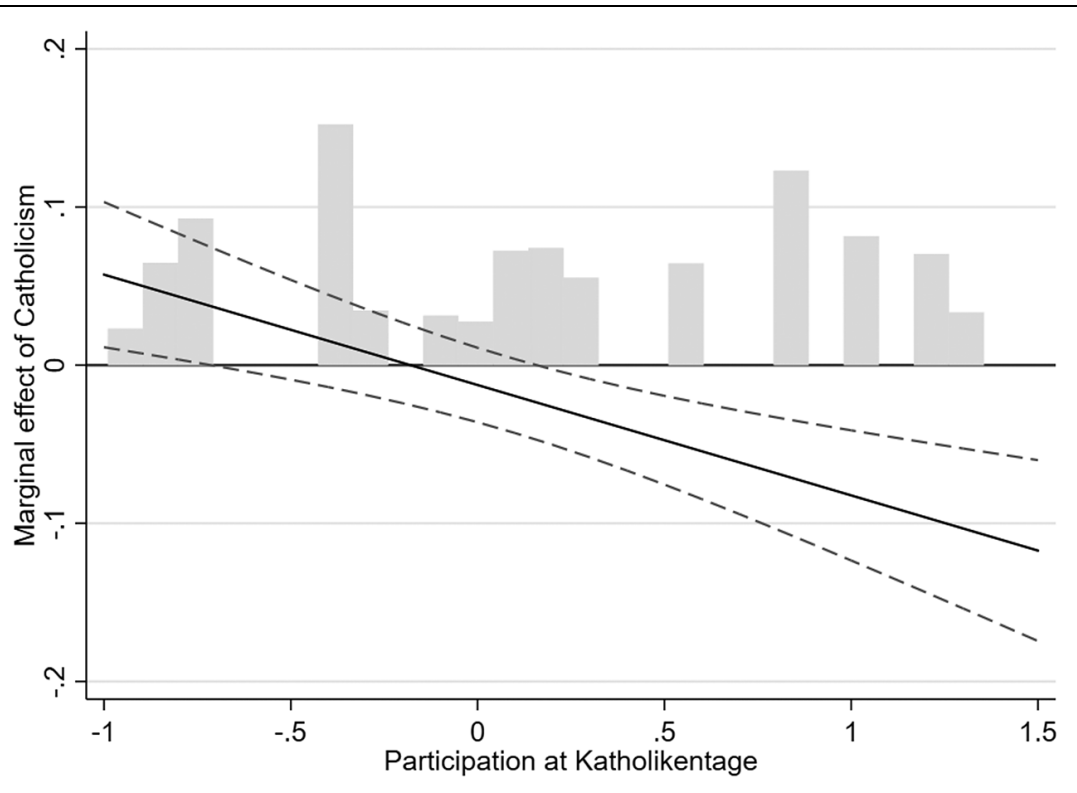

\section{FIGURE 9. Centre Party Vote Shares in Reichstag Elections, West Germany}

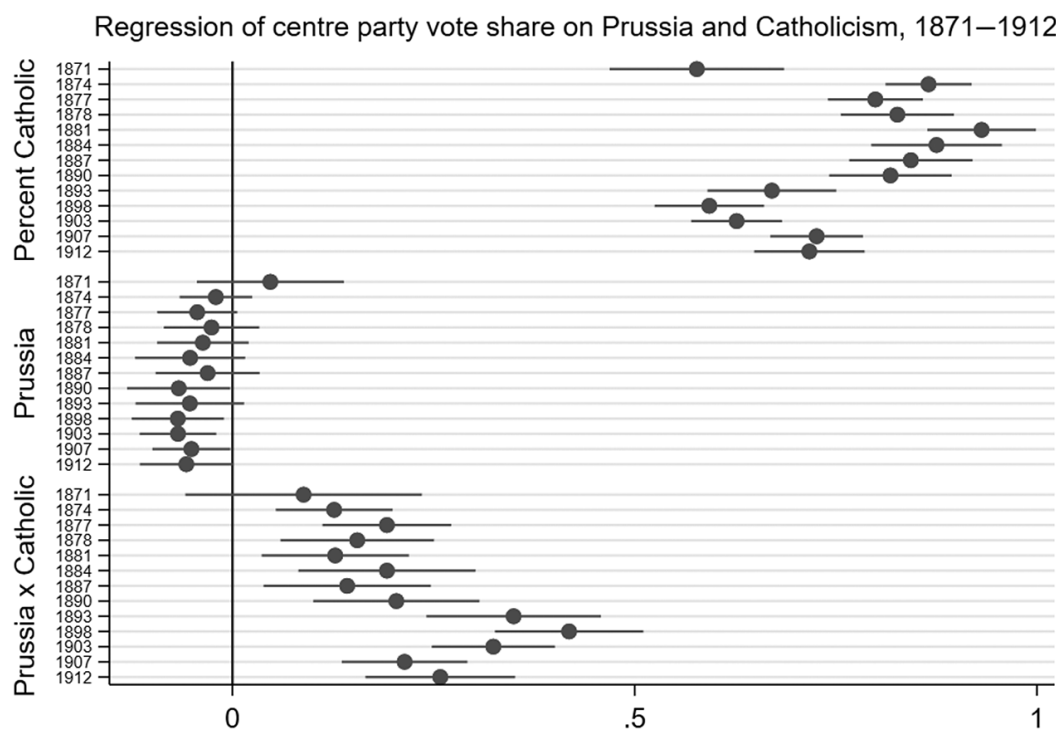

Note: $95 \%$ confidence intervals displayed.

Catholics who actually go to church most resistant to the AfD. I test for this possibility (in an admittedly coarse way), using official data on average church attendance by diocese provided by the German Bishops' Conference (Model 4). As the analysis shows, there is no evidence that Catholics in dioceses with higher Church attendance are more reluctant to support the AfD. To the contrary, church attendance and AfD support are significantly positively associated.

Because my argument focuses on the role of civil society organizations for persistence, the analyses presented here have focused on these organizations. Of course, it is also an interesting question whether there were already differences in the electoral behavior of Catholics in the German empire and the interwar period. In Figure 9, I test whether the initial mobilization of the Catholic party, the Centre Party, differed by region. It shows the results of models that regress the electoral district vote share of the Centre Party on the Catholic population share and its interaction with Prussia for West German districts in each of the 13 Reichstag elections held between 1871 and 1912. The models control for a number of indicators for the economic and demographic structure of the electoral districts in 
TABLE 5. NSDAP Results and Catholicism

\begin{tabular}{|c|c|c|c|c|c|}
\hline & (1) & $(2)$ & (3) & (4) & (5) \\
\hline DV: NSDAP vote share & 1932 Nov, fixed & 1930 & 1932, July & 1932, Nov & 1933 \\
\hline Catholic & $\begin{array}{l}-0.282^{\star \star \star} \\
(0.052)\end{array}$ & $\begin{array}{l}-0.087^{\star *} \\
(0.025)\end{array}$ & $\begin{array}{c}-0.289^{\star \star \star} \\
(0.045)\end{array}$ & $\begin{array}{c}-0.246^{\star \star *} \\
(0.045)\end{array}$ & $\begin{array}{c}-0.228^{\star \star \star} \\
(0.030)\end{array}$ \\
\hline Prussia & $\begin{array}{c}1.768 \\
(1.658)\end{array}$ & $\begin{array}{l}3.410^{\star *} \\
(1.146)\end{array}$ & $\begin{array}{l}3.462^{*} \\
(1.637)\end{array}$ & $\begin{array}{l}3.274^{+} \\
(1.748)\end{array}$ & $\begin{array}{l}4.405^{\star *} \\
(1.276)\end{array}$ \\
\hline Prussia $\times$ Catholic & $\begin{array}{l}-0.012 \\
(0.053)\end{array}$ & $\begin{array}{c}-0.065^{\star *} \\
(0.023)\end{array}$ & $\begin{array}{l}-0.038 \\
(0.037)\end{array}$ & $\begin{array}{l}-0.048 \\
(0.038)\end{array}$ & $\begin{array}{c}-0.050^{+} \\
(0.026)\end{array}$ \\
\hline Controls & YES & YES & YES & YES & YES \\
\hline District fixed effects & YES & NO & NO & NO & NO \\
\hline $\begin{array}{l}N \\
R^{2}\end{array}$ & $\begin{array}{c}982 \\
0.820\end{array}$ & $\begin{array}{c}977 \\
0.475\end{array}$ & $\begin{array}{c}979 \\
0.747\end{array}$ & $\begin{array}{c}982 \\
0.681\end{array}$ & $\begin{array}{c}981 \\
0.752\end{array}$ \\
\hline
\end{tabular}

the 1890s (for full results and alternative specifications see Appendix G). The Centre Party consistently performed stronger in Prussian districts. Moreover, this difference became stronger over time, when the near 1:1 association of Catholicism and Centre vote shares that existed in the 1870s started to fade in other parts of the country but remained in Prussia.

For the interwar period, Spenkuch and Tillmann (2018) do not find any difference between Catholic voting behavior inside and outside of Prussia. However, they focus on a different mechanism: the role of the clergy, which would not have been affected by the mobilization of the Catholic civil society. Nevertheless, Table 5 looks more closely at NSDAP results in the 1930s. I modify their model in one crucial respect, by removing electoral district fixed effects. There were 35 electoral districts in the Weimar Republic. Including them makes sense theoretically, as parties nominated separate lists in these districts, so-called "Kreiswahlvorschläge." However, the majority of the districts was either completely within Prussia or completely outside of Prussia. Including these fixed effects thus soaks up most of any potential Prussia effect.

Model 1 analyzes the election of November 1932 (the main election analyzed in Spenkuch and Tillmann 2018) on the county level and includes electoral district fixed effects. Models 2-5 analyze the elections from September 1930, July 1932, November 1932, and March 1933 but leave out the fixed effects. Otherwise, I include the whole battery of controls that is also included in the original analysis. Moreover, I still cluster standard errors at the district level in all models.

The size of the Prussia effect is considerably bigger in the models without fixed effects than in the fixed-effect model (a similar effect does not arise for removing state-fixed effects in the contemporary analysis, see Appendix C). However, it only reaches conventional levels of significance in the election of 1930 and, marginally, in the election of 1933. Interestingly, the by far strongest effect occurred in the election of September 1930-that is, before the Catholic bishops hardened their position against the NSDAP (Scholder [1977] 2000, 343). Thus, this was the election in which the elite mechanism was arguably weakest. Depending on the model specification, there is thus some weak evidence that a similar difference in voting behavior was also present in the interwar period. However, the strong presence of the elite-based mechanism dampened such differences. As Appendix $\mathrm{H}$ shows for the Presidential Election of 1925, in an election where elites were split, the difference between Prussia and Bavaria becomes clearly visible.

\section{Evidence on the Individual Level}

So far, I have only analyzed aggregate election results. While I tried to minimize the danger of an ecological fallacy in several ways, there remains a risk that my results are driven by the behavior of non-Catholics. I therefore move to the individual level using the cumulated pre- and postelection cross-section of the GLES. Individual-level data offer a particularly hard test for my hypothesis because the effect of regional historical Catholic mobilization is not necessarily restricted to members of the Catholic Church. First, it may have also affected people who left the Church as adults. Second, in regions where Catholicism has a prominent role in society, the effect may spill over to non-Catholics. Only estimating an effect for Church members thus arguably underestimates the effect of the historical mobilization of Catholics.

A second challenge is that the number of AfD voters in standard surveys is relatively small. In the GLES dataset, there are only 39 West German Catholics who report to have voted for the AfD. So rather than studying reported AfD voting, I use an 11-point feeling thermometer that asks people about their general view of a party. This measure also fits my theoretical argument, as I argue that Prussian Catholics should display greater resistance toward the AfD. This resistance is most pronounced among those who give the AfD the lowest possible thermometer score (a full $62 \%$ of West Germans, compared with just $2 \%$ for the SPD and 3\% for the CDU, respectively). I thus dichotomize the dependent variable into those most resistant (lowest thermometer score) and those at least somewhat open 


\section{FIGURE 10. Share of West Germans Most Opposed to the AfD}

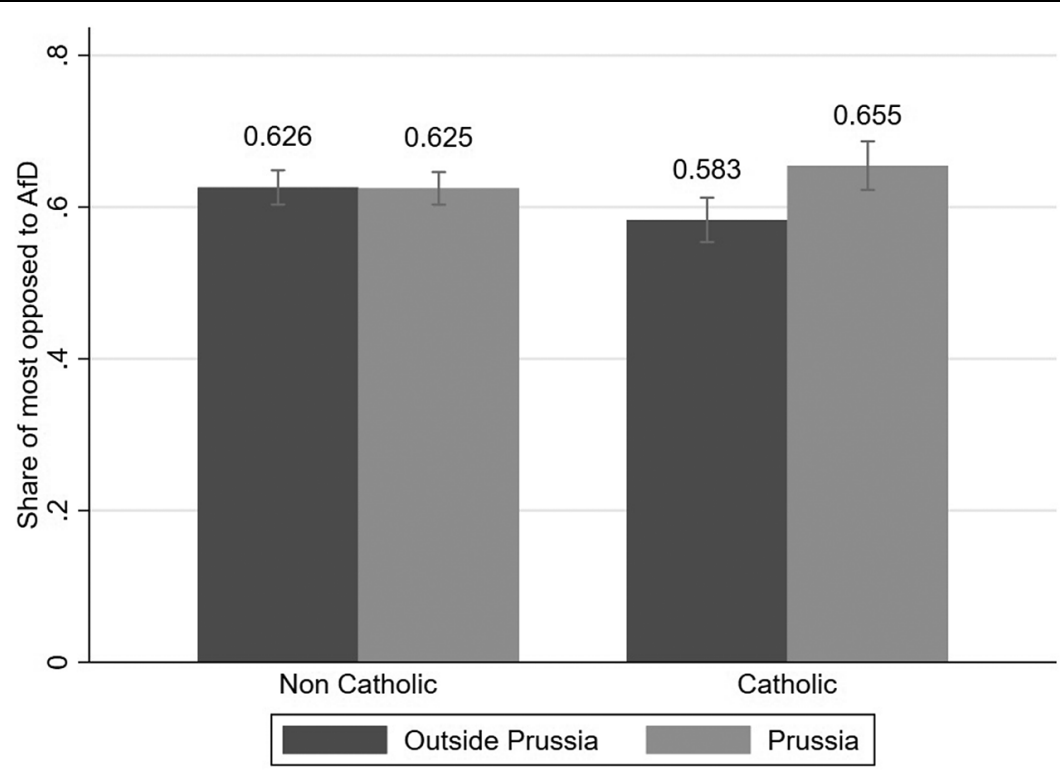

Note: $83 \%$ confidence intervals displayed.

to the AfD (everybody else). Figure 10 reports the share of (non-)Catholics within and outside of former Prussia who report the strongest opposition to the AfD. ${ }^{12}$ As the graph shows, there is no discernible difference between non-Catholics within and outside of former Prussia. Among Catholics, however, such a difference does exist: The share of Prussian Catholics who report the strongest opposition to the AfD is more than 7 percentage points higher than the share of nonPrussian Catholics. For comparison, the gap between East and West Germans on this scale is 11 percentage points, while the gap between men and women is 14 percentage points. The effect size of Prussianness is thus between half and two thirds of the effect size of the two strongest predictors of attitudes toward the AfD.

In Table 6, I analyze whether this difference remains statistically significant when controlling for a number of alternative explanations. To maintain consistency with the models at the aggregate level, I recode the variable such that a negative coefficient corresponds to a higher likelihood of reporting maximal opposition to the AfD (and thus a lower likelihood of supporting it). The table reports the results of a set of logit models that seek to explain AfD affinity among Catholics. ${ }^{13}$ As control variables, I include gender, age, level of education, household income, and employment status. Because respondents are sampled in electoral districts, I cluster

\footnotetext{
12 The GLES contains the electoral district in which respondents live. In mixed districts, I assign individuals a "Prussianness score" that is equivalent to the share of the district population living in Prussian municipalities. In Figure 10, I treat individuals as "Prussian" if their district is more than $50 \%$ Prussian.

${ }^{13}$ In Appendix I, I estimate an equivalent model for all respondents with very similar results.
}

standard errors at this level. Because the survey does not contain any Catholic respondents from either Prussian or non-Prussian districts in several states, I refrain from adding state-level fixed effects.

Both measures of historical oppression in a voter's district are negatively related to support for the AfD, although only the effect of the Prussia measure is statistically significant. To test for the mechanism of historical persistence, I include my three familiar measures: Volksverein membership in 1913 and 1927 and Katholikentag participation. All three measures are significantly associated with lower support for the AfD.

Taken together, the individual-level data thus lend further support to the findings of the aggregate analysis: Catholics in regions which experienced higher degrees of historical oppression and regions with greater levels of Catholic mobilization seem to be more opposed to the AfD than Catholics elsewhere.

\section{DISCUSSION}

This study empirically demonstrates that regional differences in the development of political Catholicism in the nineteenth and twentieth centuries still shape the development of the German party system and the regionally differentiated rise of the radical right today. When taking these differences into account, the share of Catholics in a West German region has a strong effect on the AfD vote share. In regions where Catholics were historically oppressed, the AfD vote share in more Catholic municipalities is significantly smaller than in less Catholic municipalities. In regions which did not experience oppression, by contrast, Catholicism is not associated with lower AfD vote shares. 
TABLE 6. Predicted Affinity toward the AfD, GLES 2017

\begin{tabular}{|c|c|c|c|c|c|}
\hline & (1) & (2) & (3) & (4) & (5) \\
\hline DV: Feeling toward AfD & Prussia & Kulturkampf & Volksverein 1913 & Volksverein 1927 & Katholikentag \\
\hline Prussia & $\begin{array}{c}-0.417^{\star} \\
(0.168)\end{array}$ & & & & \\
\hline Kulturkampf intensity & & $\begin{array}{l}-0.024 \\
(0.032)\end{array}$ & & & \\
\hline Volksverein 1913 & & & $\begin{array}{c}-0.108^{\star \star} \\
(0.038)\end{array}$ & & \\
\hline Volksverein 1927 & & & & $\begin{array}{c}-0.209^{\star *} \\
(0.070)\end{array}$ & \\
\hline Katholikentag & & & & & $\begin{array}{c}-0.380^{\star \star} \\
(0.134)\end{array}$ \\
\hline Female & $\begin{array}{c}-0.598^{\star \star \star} \\
(0.170)\end{array}$ & $\begin{array}{c}-0.585^{\star \star \star} \\
(0.168)\end{array}$ & $\begin{array}{c}-0.601^{\star \star \star} \\
(0.170)\end{array}$ & $\begin{array}{c}-0.604^{\star \star \star} \\
(0.169)\end{array}$ & $\begin{array}{c}-0.585^{\star \star \star} \\
(0.166)\end{array}$ \\
\hline Age & $\begin{array}{l}-0.006 \\
(0.005)\end{array}$ & $\begin{array}{l}-0.006 \\
(0.005)\end{array}$ & $\begin{array}{l}-0.005 \\
(0.005)\end{array}$ & $\begin{array}{l}-0.006 \\
(0.005)\end{array}$ & $\begin{array}{l}-0.006 \\
(0.005)\end{array}$ \\
\hline Education high & $\begin{array}{c}-0.644^{\star \star} \\
(0.197)\end{array}$ & $\begin{array}{c}-0.638^{\star *} \\
(0.196)\end{array}$ & $\begin{array}{c}-0.596^{\star *} \\
(0.196)\end{array}$ & $\begin{array}{c}-0.589^{\star *} \\
(0.196)\end{array}$ & $\begin{array}{c}-0.586^{\star *} \\
(0.190)\end{array}$ \\
\hline Unemployed & $\begin{array}{l}-0.110 \\
(0.344)\end{array}$ & $\begin{array}{l}-0.162 \\
(0.349)\end{array}$ & $\begin{array}{l}-0.078 \\
(0.340)\end{array}$ & $\begin{array}{l}-0.096 \\
(0.338)\end{array}$ & $\begin{array}{l}-0.090 \\
(0.343)\end{array}$ \\
\hline Household income & $\begin{array}{l}-0.010 \\
(0.063)\end{array}$ & $\begin{array}{l}-0.017 \\
(0.064)\end{array}$ & $\begin{array}{l}-0.011 \\
(0.064)\end{array}$ & $\begin{array}{l}-0.006 \\
(0.064)\end{array}$ & $\begin{array}{l}-0.002 \\
(0.064)\end{array}$ \\
\hline Constant & $\begin{array}{c}1.118^{\star} \\
(0.477)\end{array}$ & $\begin{array}{c}1.042^{*} \\
(0.483)\end{array}$ & $\begin{array}{l}1.355^{\star \star} \\
(0.486)\end{array}$ & $\begin{array}{l}1.308^{\star \star} \\
(0.463)\end{array}$ & $\begin{array}{l}0.819^{+} \\
(0.464)\end{array}$ \\
\hline$N$ & 789 & 789 & 789 & 789 & 789 \\
\hline$R^{2}$ & 0.034 & 0.027 & 0.035 & 0.036 & 0.037 \\
\hline
\end{tabular}

The study demonstrates this empirical regularity on different levels of aggregation and explains it with the divergent development of political Catholicism. In German states where Catholics were oppressed, in particular in Prussia, they developed a tight, strongly organized milieu in which they separated themselves from the state, but also from the clerical hierarchy. By contrast, political Catholicism in Southern Germany remained more closely related to the Church and was less driven by laity. When the Church began losing its influence over the voting behavior of the faithful, there was thus no equifinal mechanism that stopped Southern German Catholics from supporting the radical right.

My findings have important implications for the literature on the persistence of historical political alignments as well as for the literature on the rise of the radical right. With respect to the former, the paper emphasizes the role that civil society mobilization can play in the transmission of historical experiences. Meso-level organizations do not just contribute to the explanation of persistence as such but are particularly useful to explain regionally differentiated patterns of persistence. At the same time, my findings raise the question of what happens when these organizations come under pressure. The German Catholic Church sees its membership decline rapidly and the Catholic milieu has largely disappeared.

With respect to the rise of the radical right, the paper's results demonstrate the importance of a regionally differentiated understanding of the conditions that promote or inhibit this rise. Attempts to identify factors that consistently explain the performance of the radical right across an entire country run the risk of overlooking important but regionally differentiated factors. In this sense, this study is a plea to look not just for master narratives of "modernization losers" or "cultural backlash," but to remain alert to the specific historical and cultural context factors that contribute to the success or failure of the radical right.

Moreover, the study highlights that a complete understanding of the rise of the radical right also requires studying the factors that may prevent people from voting for these parties. In this view, radical-right voting is the outcome of a balancing of factors that make these parties an attractive choice and factors that deter voters from supporting them. A growing strength of right-wing authoritarians may have as much to do with the declining force of the deterring factors as with a growing force of attracting factors. Where deterring forces are still strong, as in some Catholic parts of Germany, even a growing strength of the attracting factors may only have a minor effect on electoral results.

\section{SUPPLEMENTARY MATERIALS}

To view supplementary material for this article, please visit http://doi.org/10.1017/S0003055421001040. 


\section{DATA AVAILABILITY STATEMENT}

Research documentation and data that support the findings of this study are openly available at the APSR Dataverse: https://doi.org/10.7910/DVN/MURIT2.

\section{ACKNOWLEDGMENTS}

Earlier versions of this paper were presented at the Swiss Political Science Association annual meeting in Zurich in February 2019 and the Conference of Europeanists in Madrid in June 2019. I would like to thank Reto Mitteregger and Ursina Storrer for excellent research assistance, Philip Manow and Hanna Schwander for generously sharing data, Antonius Liedhegener and Gabriel Rolfes for invaluable pointers to sources on political Catholicism, Hubert Wissing for helping with collecting data on Katholikentag participation, and Nils Redeker, Valentin Lang, Silja Häusermann, Lukas Rudolph, Svenja Hense, Daniel Bischof, Kai Gehring, Josef Hien, and Delia Zollinger for helpful comments.

\section{CONFLICT OF INTEREST}

The author declares no ethical issues or conflicts of interest in this research.

\section{ETHICAL STANDARDS}

The author affirms this research did not involve human subjects.

\section{REFERENCES}

Acharya, Avidit, Matthew Blackwell, and Maya Sen. 2016. "A Culture of Disenfranchisement: How American Slavery Continues to Affect Voting Behavior." Working Paper.

Anderson, Margaret Lavinia. 1986. "The Kulturkampf and the Course of German History." Central European History 19: 82-115. Apfeld, Brendan. 2019. "Spatial and Temporal University Database." Working Paper, University of Texas.

Arbeitskreis für kirchliche Zeitgeschichte. 2000. "Konfession und Cleavages im 19. Jahrhundert. Ein Erklärungsmodell zur Regionalen Entstehung des Katholischen Milieus in Deutschland." Historisches Jahrbuch 120: 358-95.

Arzheimer, Kai, and Carl C. Berning. 2019. "How the Alternative for Germany (AfD) and Their Voters Veered to the Radical Right, 2013-2017." Electoral Studies 60: Article 102040.

Arzheimer, Kai, and Elisabeth Carter. 2009. "Christian Religiosity and Voting for West European Radical Right Parties." West European Politics 32 (5): 985-1011.

Barro, Robert, and Rachel McCleary. 2016. "Saints Marching in, 1590-2012." Economica 83: 385-415.

Bergmann, Knut, Matthias Diermeier, and Judith Niehues. 2018. "Ein Komplexes Gebilde. Eine Sozio-Ökonomische Analyse des Ergebnisses der AfD bei der Bundestagswahl 2017." Zeitschrift für Parlamentsfragen 49: 243-64.

Bruce, Steve. 2003. Politics and Religion. Cambridge: Polity. Cantoni, Davide, Felix Hagemeister, and Mark Westcott. 2019. "Persistence and Activation of Right-Wing Political Ideology."
Working Paper. https://rationality-and-competition.de/wpcontent/uploads/discussion_paper/143.pdf.

Coffé, Hilde, Bruno Heyndels, and Jan Vermeir. 2007. "Fertile Grounds for Extreme Right-Wing Parties: Explaining the Vlaams Blok's Electoral Success.” Electoral Studies 26: 142-55.

Colantone, Italo, and Piero Stanig. 2018. "The Trade Origins of Economic Nationalism: Import Competition and Voting Behavior in Western Europe." American Journal of Political Science 62 (4): 936-53.

Colella, Fabrizio, Rafael Lalive, Seyhun Orcan Sakalli, and Mathias Thoenig. 2019. "Inference with Arbitrary Clustering." IZA DP 12584.

Elff, Martin, and Sigrid Rossteutscher. 2011. "Stability or Decline? Class, Religion and the Vote in Germany." German Politics 20 (1): 107-27.

Falter, Jürgen W. 1991. Hitlers Wähler. München: Beck.

Fitzgerald, Jennifer. 2018. Close to Home: Local Ties and Voting Radical Right in Europe. Cambridge: Cambridge University Press.

Gidron, Noam, and Peter A. Hall. 2017. "The Politics of Social Status: Economic and Cultural Roots of the Populist Right." British Journal of Sociology 68 (S1): S57-S84.

Gingrich, Jane, and Julia Lynch. 2019. "Integrative Institutions and Mainstream Party Collapse: The Regional Context." Paper presented at the Max-Planck-Institute for the Study of Societies, October 2019.

Giuliano, Paola, and Romain Wacziarg. 2020. "Who Voted for Trump? Populism and Social Capital.” NBER Working Paper No. 27651.

Großbölting, Thomas. 2013. Der Verlorene Himmel. Glaube in Deutschland Seit 1945. Göttingen: Vandenhoeck \& Ruprecht.

Harteveld, Eelco, Wouter van der Brug, Sarah De Lange, and Tom van der Meer. 2021. "Multiple Roots of the Populist Radical Right: Support for the Dutch PVV in Cities and the Countryside." European Journal of Political Research Online First.

Haffert, Lukas. 2021. "Replication Data for: The Long-Term Effects of Oppression: Prussia, Political Catholicism and the Alternative für Deutschland." Harvard Dataverse. Dataset. https:// doi.org/10.7910/DVN/MURIT2.

Heitzer, Horstwalter. 1979. Der Volksverein Für Das Katholische Deutschland Im Kaiserreich, 1890-1918. Mainz: MatthiasGrünewald-Verlag.

Hoerner, Julian M., Alexander Jaax, and Toni Rodon. 2019. “The Long-Term Impact of the Location of Concentration Camps on Radical-Right Voting in Germany." Research \& Politics 6 (4): 1-8.

Homola, Jonathan, Miguel M. Pereira, and Margit Tavits. 2020. "Legacies of the Third Reich: Concentration Camps and OutGroup Intolerance." American Political Science Review 114 (2): 573-90.

Immerzeel, Tim, Eva Jaspers, and Marcel Lubbers. 2013. "Religion as Catalyst or Restraint of Radical Right Voting?" West European Politics 36 (5): 946-68.

Inglehart, Ronald F., and Pippa Norris. 2016. "Trump, Brexit, and the Rise of Populism: Economic Have-Nots and Cultural Backlash.” KS Faculty Research Working Paper Series RWP16-026.

Jäckle, Sebastian, Uwe Wagschal, and Andreas Kattler. 2018. "Distanz zur Grenze als Indikator für den Erfolg der AfD bei der Bundestagswahl 2017 in Bayern?" Zeitschrift für Vergleichende Politikwissenschaft 12 (3): 539-66.

Jones, Larry Eugene. 2000. "Catholic Conservatives in the Weimar Republic: The Politics of the Rhenish-Westphalian Aristocracy, 1918-1933." German History 18: 60-85.

Katholische Kirche in Deutschland. 2020. Zahlen und Fakten 2019/2020. Bonn: Sekretariat der Deutschen Bischofskonferenz.

Klein, Gotthard. 1996. Der Volksverein für das Katholische Deutschland 1890-1933. Geschichte, Bedeutung, Untergang. Paderborn: F. Schöningh.

Kösters, Christoph, Claudio Kullmann, Antonius Liedhegener, and Wolfgang Tischner. 2009. "Was kommt nach dem katholischen Milieu? Forschungsbericht zur Geschichte des Katholizismus in Deutschland in der zweiten Hälfte des 20. Jahrhunderts." Archiv für Sozialgeschichte 49: 485-526.

Lepsius, M. Rainer. 1966. "Parteiensystem und Sozialstruktur: Zum Problem der Demokratisierung der Deutschen Gesellschaft." In Wirtschaft, Geschichte und Wirtschaftsgeschichte. Festschrift zum Geburtstag Von Friedrich Lütge, eds. Wilhelm Abel, Knut 
Borchardt, Hermann Kellenbenz, and Wolfgang Zorn, 371-93. Stuttgart: Gustav Fischer.

Lönne, Karl-Egon. 1986. Politischer Katholizismus im 19. und 20. Jahrhundert. Frankfurt: Suhrkamp.

Lösche, Peter, and Franz Walter. 2000. "Katholiken, Konservative und Liberale: Milieus und Lebenswelten Bürgerlicher Parteien in Deutschland Während des 20. Jahrhunderts." Geschichte und Gesellschaft 26: 471-92.

Meyer, Nonna. 2013. "From Jean-Marie to Marine Le Pen: Electoral Change on the Far Right." Parliamentary Affairs 66: 160-78.

Minkenberg, Michael. 2018. "Religion and the Radical Right." In The Oxford Handbook of the Radical Right, ed. Jens Rydgren, 366-93. Oxford: Oxford University Press.

Neundorf, Anja, and Grigore Pop-Eleches. 2020. "Dictators and Their Subjects: Authoritarian Attitudinal Effects and Legacies." Comparative Political Studies 53 (12): 1839-60.

Nipperdey, Thomas. 1961. Die Organisation der Deutschen Parteien vor 1918. Düsseldorf: Droste.

Ochsner, Christian, and Felix Roesel. 2017. "Activated History: The Case of the Turkish Sieges of Vienna." CESifo Working Paper 6586.

Peisakhin, Leonid, and Volha Charnysh. 2021. "The Role of Communities in the Transmission of Political Values: Evidence from Forced Population Transfers.” British Journal of Political Science, 1-21. doi:10.1017/S0007123420000447.

Pop-Eleches, Grigore, and Joshua A Tucker. 2017. Communism's Shadow: Historical Legacies and Contemporary Political Attitudes. Princeton, NJ: Princeton University Press.

Putnam, Robert. 1993. Making Democracy Work: Civic Traditions in Modern Italy. Princeton, NJ: Princeton University Press.

Richter, Christoph, and Lukas Bösch. 2017. Demokratieferne Räume? Wahlkreisanalyse zur Bundestagswahl 2017. Jena: Institut für Demokratie und Zivilgesellschaft.

Ross, Ronald J. 1998. The Failure of Bismarck's Kulturkampf: Catholicism and State Power in Imperial Germany, 1871-1887. Washington, DC: Catholic University of America Press.
Rydgren, Jens. 2009. "Social Isolation? Social Capital and Radical Right-Wing Voting in Western Europe." Journal of Civil Society 5 (2): 129-50.

Scholder, Klaus. [1977] 2000. Die Kirchen und Das Dritte Reich. Bd.1: Vorgeschichte und Zeit der Illusionen, 1918-1934. Berlin: Propyläen.

Scholz, Bastian. 2016. Die Kirchen und der Deutsche Nationalstaat. Konfessionelle Beiträge zum Systembestand und Systemwechsel. Wiesbaden: Springer VS.

Siegers, Pascal, and Alexander Jedinger. 2021. "Religious Immunity to Populism: Christian Religiosity and Public Support for the Alternative for Germany." German Politics 30 (2): 149-69.

Spenkuch, Jörg L., and Philipp Tillmann. 2018. "Elite Influence? Religion and the Electoral Success of the Nazis." American Journal of Political Science 62 (1): 19-36.

Strötz, Jürgen. 2005. Der Katholizismus im Deutschen Kaiserreich 1871 bis 1918. Strukturen Eines Problematischen Verhältnisses Zwischen Widerstand und Integration. Hamburg: Verlag Dr. Kovac.

Voigtländer, Nico, and Hans-Joachim Voth. 2012. "Persecution Perpetuated: The Medieval Origins of Anti-Semitic Violence in Nazi Germany." The Quarterly Journal of Economics 127 (3): 1339-92.

Wittenberg, Jason. 2006. Crucibles of Political Loyalty: Church Institutions and Electoral Continuity in Hungary. Cambridge: Cambridge University Press.

Zentralkomitee der deutschen Katholiken. 2018. "ZdK-Präsident Prof. Dr. Thomas Sternberg: 'Die Afd Ist Rechtsradikal."' https://www.zdk.de/veroeffentlichungen/meldungen/detail/ ZdKPraesident-Prof-Dr-Thomas-Sternberg-Die-AfD-istrechtsradikal--122g/.

Ziemann, Benjamin. 2000. "Der Deutsche Katholizismus im späten 19. und 20. Jahrhundert. Forschungstendenzen auf dem Weg Sozialgeschichtlicher Fundierung und Erweiterung." Archiv für Sozialgeschichte 40: 402-22. 